\title{
Cocktail Anti-Tick Vaccines: The Unforeseen Constraints and Approaches toward Enhanced Efficacies
}

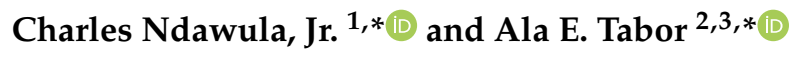 \\ 1 Vaccinology Research Program, National Livestock Resources Research Institute, P O. Box 5746, \\ Nakyesasa 256, Uganda \\ 2 Centre for Animal Science, Queensland Alliance for Agriculture \& Food Innovation, \\ The University of Queensland Australia, St Lucia 4072, Queensland, Australia \\ 3 School of Chemistry \& Molecular Biosciences, The University of Queensland, St Lucia 4072, \\ Queensland, Australia \\ * Correspondence: ndawulaj821@gmail.com (C.N.J.); a.tabor@uq.edu.au (A.E.T.)
}

Received: 20 July 2020; Accepted: 13 August 2020; Published: 19 August 2020

\begin{abstract}
Ticks are second to mosquitoes as vectors of disease. Ticks affect livestock industries in Asia, Africa and Australia at $\sim \$ 1.13$ billion USD per annum. For instance, $80 \%$ of the global cattle population is at risk of infestation by the Rhipicephalus microplus species-complex, which in 2016 was estimated to cause \$22-30 billion USD annual losses. Although the management of tick populations mainly relies on the application of acaricides, this raises concerns due to tick resistance and accumulation of chemical residues in milk, meat, and the environment. To counteract acaricide-resistant tick populations, immunological tick control is regarded among the most promising sustainable strategies. Indeed, immense efforts have been devoted toward identifying tick vaccine antigens. Until now, Bm86-based vaccines have been the most effective under field conditions, but they have shown mixed success worldwide. Currently, of the two Bm86 vaccines commercialized in the 1990s (Gavac ${ }^{\mathrm{TM}}$ in Cuba and TickGARD ${ }^{\text {PLUSTM }}$ in Australia), only Gavac ${ }^{\mathrm{TM}}$ is available. There is thus growing consensus that combining antigens could broaden the protection range and enhance the efficacies of tick vaccines. Yet, the anticipated outcomes have not been achieved under field conditions. Therefore, this review demystifies the potential limitations and proposes ways of sustaining enhanced cocktail tick vaccine efficacy.
\end{abstract}

Keywords: cocktail tick-vaccines; antigen competition; tick-acaricide resistance; anti-tick vaccines

\section{Introduction}

Ticks are obligate blood-feeding parasites that are capable of transmitting pathogens both to humans and animals [1,2]. Most of the ticks circulating globally belong to two families-the Ixodidae (hard ticks) and Argasidae (soft ticks); one tick species belongs to the Nuttalliellidae [3]. In the late 1990s, the impact of Ixodid ticks of genera: Dermacentor, Hyalomma, Rhipicephalus, Haemaphysalis) on livestock in Africa, Asia and Australia was estimated at $~ \$ U S D 708 \mathrm{~m}[4]$, which currently equates to losses of $\$ 1.13$ billion USD per annum. In 1997, particularly, Rhipicephalus microplus species-complex alone was estimated at \$13.9-18.7 billion USD per annum globally, which translates to $\$ 22-30$ billion USD in 2016 [5,6]. Currently, the spread of R. microplus species-complex to other regions [7-10] is likely to increase the burden of tick species infestation and tick-borne diseases globally. On the other hand, Argasid tick species of the genus Ornithodorus transmit the African swine fever virus, which causes a fatal haemorrhagic fever disease in pigs that leads to $100 \%$ mortality which severely affects the pig-industry of sub-Saharan Africa, Asia, eastern Europe [11]. Despite the fact that great success of 
Ixodid-tick control has been achieved using acaricides (anti-tick pesticides), there are increasing reports of acaricide resistance [12,13]. Similarly, acaricides could be used to control Argasid ticks [14,15], yet there is still concern over whether acaricides can be applied effectively given the endophilic lifestyle of Argasids [16]. Nonetheless, excessive use of acaricides can lead to accumulation of chemical residues in milk, meat, and the environment [17]. For these reasons, alternative approaches to tick control have been suggested [18], of which vaccination or immunological control is regarded the most promising, environmentally friendly, and sustainable strategy. To date, numerous antigens have been reported to induce protection against Ixodid ticks [18-21] and less against Argasids [22-24]. Earlier, Willadsen [25] questioned whether combining antigens toward enhanced efficacy is a valid hypothesis. In response, research groups have investigated the concept of cocktail vaccines against Ixodid and Argasid ticks, as summarized in Table 1. Until now, however, the concept remains unsubstantiated under field conditions. Therefore, the goal of this review is to examine the probable constraints and approaches for enhancing the efficacy of cocktail tick vaccines.

\section{Historical Background of Tick Vaccine Antigens}

The concept of tick vaccines was first demonstrated in 1939 [26]. Initially, Trager [26] observed that repeated tick larvae infestations triggered an acquired immune resistance against Ixodid ticks in guinea pig and rabbit models. A similar phenomenon was observed when guinea pigs were inoculated with native protein tissue-extracts from Dermacentor variabilis ticks [27]. Subsequently, in 1940, Trager [28] demonstrated that Argasid ticks can also induce partial acquired immunity in chickens. The acquired immune resistance was determined to be based on a reduced number of engorged ticks, reduced blood-feeding, and reduced weight and viability of eggs [29]. Then, the question arose as to how the acquired immune resistance affects the ticks' physiological parameters. Partially in response, different research groups have reported that the hosts' antibodies/immunoglobulins (IgGs) can traverse the tick gut epithelium to the hemolymph and other tick tissues [30-32]. Furthermore, the antibodies induced against particular tick vaccine antigens are shown to react against the corresponding tick tissue proteins [33]. Therefore, it is presumed that when ingested during blood feeding, the anti-tick antigen sera could interfere with the physiological functionality of internal tick proteins.

Building on these observations, numerous recombinant tick antigens have been identified against Ixodid ticks [18-21], of which Bm86 is still the most successful under field conditions [34,35]. Additionally, Bm86 is shown to induce cross-protection against different tick species, but not against species such as Amblyomma variegatum and Rhipicephalus appendiculatus which affect livestock in Africa [36]. Other tick vaccine antigens-for instance, subolesin [37], glutathione S-transferase (GST) [38,39], cement protein (64TRP) [40]—have also been reported to induce cross-protection against different Ixodid ticks. By contrast, although Trager [28] and several other research groups [22] have demonstrated that Agarsid tick-extracts can induce acquired immunity in vivo, the progress toward the development of subunit vaccines against Argasids has been slow. Certainly, there are reasons for this slow progress which will not be addressed in this review. Therefore, it is not coincidental that to date only a few single vaccines against Argasids have been reported [22-24]. Nonetheless, tick researchers still aim to develop good vaccines which are able to induce a substantial humoral/or cell mediated protective immune responses in Argasid and Ixodid ticks. However, that is not the only factor that determines an ideal anti-tick vaccine. For instance, with reference to Ixodid ticks, Díaz-Martín et al. [22] presented the desired attributes of an ideal anti-tick vaccine. In general, the efficacy of a particular tick-vaccine can be influenced by factors such as the immunogenicity of the proteins and the host's immune response.

Finally, in comparison to other vectors and pathogens, ticks are reported to have very large genomes (2.1-7.1Gb) [41,42]. Moreover, tick genomes are highly repetitive-a phenomenon that could be fundamental to tick survival. It is, therefore, likely that ticks express a plethora of proteins depending on their environment. This further supports the hypothesis that the provision of cocktail vaccine antigens could enhance anti-tick protection efficacy [25]. 


\section{Approaches to Identifying Cocktail Vaccine Antigens}

\subsection{Single-Antigen Vaccine Efficacy}

Often, a cocktail tick vaccine is constituted with antigens that were previously identified based on their individual protection efficacy. Presumably, the rationale is that if antigens A and B induce protection of $45 \%$ and $55 \%$, respectively, combining the two antigens could double the protection efficacy. Interestingly, a similar approach has been embraced toward enhancing the efficacy of vector-borne pathogen vaccines $[43,44]$. Even though the approach is direct, simple, and mathematically logical, it does not take into account the potential immunological shortcomings of combining antigens. These will be discussed herein later.

Alternatively, (as shown in Table 1) several research groups have tested cocktail vaccines without previously determining individual antigen efficacies. This could be due to high cost of livestock for trial experiments. However, in this case, the cause for combining two or more antigens (to enhance the efficacy of one antigen) cannot be justified. Of course, blindly formulated cocktail vaccines may induce numerous effects, especially if the antigens were derived from proteins which play different roles in tick physiology. Nevertheless, immunological shortcomings due to combining antigens are inevitable.

\subsection{Antigen Serum Immuno-Cross-Reactivity}

Recently, the principle of independent immunogenicity of tick vaccine antigens has further been investigated toward selecting cocktail antigens [45]. Specifically, Ndawula et al. [45] demonstrated that serum independently induced against the recombinant glutathione S-transferase (rGST) cross-reacts against heterologous tick species rGSTs, although at varying intensities. Interestingly, a similar approach was earlier used toward identifying a potential broad-spectrum single tick vaccine antigen based on tick cement [40]. The approach of serum cross-reactivity, however, can only be applied while selecting among homologous tick antigens.

\subsection{Antigen Discovery Approaches}

Single tick vaccine antigens are often developed based on the genetic make-up of the tick species of interest. Indeed, the approach could also be used for identifying cocktail tick vaccine antigens. Historically, methods used commonly included RNA interference [46], expression library immunization (ELI), evaluation of expressed sequence tags [47], interactomics [48], proteomics [47], and transcriptomics [48]. However, it should be noted, that even though RNAi can be used for identifying tick antigens [49], the method is designed for studying the potential roles of target genes in tick physiology and as such may not be immunogenic [50,51]. Of the described methods, transcriptomics is most commonly used and further has been used in combination with proteomics [52,53], and metabolomics [54]. This approach has enhanced the efficiency and accuracy of antigen discovery, which could also hasten the identification of potential cocktail antigens.

\subsection{Antigen-Serum-Induced Effect}

In the quest for methods to control ticks and tick-borne diseases, feeding of ticks in the laboratory remains a major challenge; thus, the use of laboratory animals is preferred. However, animals are expensive, and their use raises ethical debates. Therefore, in vitro or artificial tick-feeding methods have been developed with the establishment of capillary [55,56], glass tube [57], and membrane [58,59], tick feeding protocols.

Artificial membrane tick feeding has since been used, for instance, in studying the effect of novel acaricide molecules on tick physiology [60], and proteins involved in pathogen transmission as targets for vaccine development [61]. Additionally, although artificial membrane feeding has been successfully used for growing ticks in vitro, the method requires twice daily defibrinated blood changes, and it can take up to eight weeks for all stages to emerge [62]. The method has been commonly used for acaricide screening but is less amenable for high throughput screening of vaccine candidates. 
By contrast, the capillary feeding method is easier, so it is commonly used to feed semi-engorged female ticks [63-65]. The limitation to this method is that the capillaries become blocked by blood hence capillaries are changed regularly. To prevent tube blockage, blood must be preserved in anti-coagulants during collection [53,59]. A concern has arisen as to whether different anti-coagulants can affect tick physiology and development. Thus, Lew-Tabor et al. [53] used glass tubes to feed semi-engorged adult female $R$. australis with antibodies or blood preserved with different anticoagulants and assessed the effect induced on the tick-weight, egg-weight and egg-viability. The findings showed that $1 \mathrm{mg} / \mathrm{mL}$ of Bm86 IgG induces the same efficacy (in vitro) as Bm86 vaccine (in vivo), which suggests that the model is reliable for screening candidate tick-vaccines.

Recently, Trentelman et al. [66] exploited in vitro tick feeding for larval stages to examine the effect of a cocktail anti-tick vaccine serum. They demonstrated that a combination of anti-Bm86 and anti-subolesin serum inhibited the feeding of Rhipicephalus australis larvae, which suggested that the antigens were candidates for a cocktail vaccine. On the contrary, however, Perner et al. [67] showed that feeding adult ticks on a meal devoid of haemoglobin leads to egg-sterility. This raises a question whether the feeding-inhibition effect induced on Rhipicephalus australis larvae [66] was partly due to the lack of haemoglobin. Following feeding, larvae were weighed, but moulting to the nymph stage was not examined. In addition, although a blood anti-coagulant was used in the study to ensure the ticks are able to feed continuously on the blood provided, there is a possibility that anticoagulants affect tick development. Along these lines, Lew-Tabor et al. [53] demonstrated that eggs laid by ticks fed on heparinized blood were viable, but not viable when ticks were fed with EDTA or CPDA blood. Therefore, while conducting in vitro tick feeding, the experiments are not deemed successful unless the next tick-life stage emerges.

Even though this discussion is based on reports from Ixodid artificial feeding experiments, we speculate that the same principles could apply to artificial feeding studies for Argasid (soft) ticks. Our hypothesis is based on evidence that in vitro artificial feeding membranes have been exploited for the maintenance of Argasid ticks (O. coriaceus and O. moubata) [68-70] and in acaricide-efficacy studies [14,15]. However, reports that examine the effect of cocktail vaccines against Argasids using in vitro artificial feeding membranes are yet to emerge. Nevertheless, artificial feeding is an important tool not only in search of vaccines against Ixodids (hard ticks) and Argasids (soft ticks), especially in the selection of tick antigens for cocktail tick vaccines. For instance, the model could be used to determine the concentration of cocktail vaccines. This view is based on evidence that vaccine protection efficacy is directly proportional to vaccine-induced antibodies [71]. The tool could also be used to assess the vaccine effect on different stages of tick development.

\section{Potential Constraints toward Cocktail Vaccine Efficacy}

\subsection{Antigenic Competition}

To date, numerous cocktail vaccines against Ixodid ticks and a few against Argasid ticks have been investigated (Table 1) with the hypothesis that combining at least two antigens could increase the protective antibody response. However, often no enhanced protection is observed coupled with reduction of antibodies against each of the cocktail antigens [72-74]. In 1902, a German immunologist, Michaelis, made a similar observation [75]. Specifically, Michaelis noted that following the inoculation of a cocktail of antigens, the immune response to one antigen was suppressed by the response to a second, unrelated antigen. This phenomenon is described as antigenic competition. Indeed, this phenomenon sparked interest among immunologists - to date, over 10 mechanisms have been proposed to explain the reduction of antibodies in cocktail vaccines. Pross and Edinger [76] thoroughly discussed the research advances that were made toward understanding the mechanism of antigenic competition. This phenomenon could also account for the reduction of immune responses against cocktail tick vaccines, but the mechanism of action remains a topic of research. Furthermore, Taussig et al. [77] revealed that the reduction of antibodies can result from inter or intra-molecular competition. Intramolecular and 
intermolecular competition occurs between the determinants on the same or different immunogen(s). It is therefore probable that intermolecular competition is common within cocktail tick vaccines consisting of heterologous or homologous antigens. Thus, the fundamental question remains; could the reduction of antibodies against the antigens explain why cocktail tick vaccines are yet to show enhanced efficacy under field conditions? It seems likely that antigenic competition is further influenced by other factors.

\subsubsection{Antigen Concentration}

Similar to other vaccines, the efficacy of tick vaccines is determined based on humoral immune responses [78]. Indeed, antigen concentration is one of the factors that influences humoral immune responses. Given that cocktail tick vaccines are aimed at enhancing efficacy, it is tempting to use a higher concentration of single antigens. Suppose that $100 \mu \mathrm{g}$ of vaccine A and B independently induced $45 \%$ and $55 \%$ efficacy, $100 \mu \mathrm{g}$ of A and B may be combined to make a cocktail vaccine. Indeed, this approach is mathematically logical, but it may trigger undesired immune responses which include

1. Increased antigenic competition. For instance, evidence indicates that inter-molecular competition increases with dose concentration $[77,79,80]$.

2. Immunotolerance. This is a condition where the immune system shows a reduced response against an antigenic substance or molecule due to prior exposure. The response is classified into high and low immunotolerance that is triggered by high or low-dose antigen concentrations, respectively [81,82]. Furthermore, the tolerance can be influenced by other factors such as the route of immunization, antigen protein molecular weight, and immunogenicity [83]. Overall, the tolerance induction mechanism is based on whether the antigens are T-cell dependent or independent $[84,85]$. However, to date, the optimum concentration for formulating cocktail tick vaccine antigens is still unknown and is likely to vary depending on the antigens within the cocktail.

\subsubsection{Antigen-Adjuvant Interaction}

The development of anti-tick vaccine antigens (subunit vaccines) mainly relies on the advances in recombinant DNA technology. In contrast to other forms of vaccines- based on native proteins, live or attenuated microorganisms- subunit vaccines can be manufactured, purified and as such, are safer. However, considering that subunit vaccines are composed of recombinant proteins, vaccines are also prone to degradation. The main drawback to subunit vaccines is that they may not elicit a sufficient protective immune response or can be poorly immunogenic [86]. Therefore, adjuvants are used to avert the limitations of subunit vaccines $[87,88]$. It should be noted that adjuvants act either as immunopotentiators or delivery systems $[89,90]$. For most anti-tick vaccine research to date, adjuvants have been involved as the primary delivery system. For instance, a lower tick rejection was reported against tick salivary gland antigen extract with Freund's complete adjuvant (FCA) compared to Freund's incomplete adjuvant (FIA) [91]. Often pilot antigen in vivo studies use a combination of FCA followed by FIA boosts, see Table 1 [74,92,93]. Imamura and co-workers [92] for instance, demonstrated that Rhipicephalus appendiculatus recombinant serine protease inhibitors (rRAS-1 and 2) delivered as a cocktail vaccine induced higher tick mortality with an adjuvant combination (FCA and FIA) compared with the single adjuvant (FIA). Even though the efficacies were not high enough to warrant commercialization of the cocktail vaccine (rRAS-1 and 2), the study demonstrated the variable impact of different adjuvant combinations. However, currently Freunds' adjuvants are not recommended for commercial use in large animals, as they induce tissue damage and painful reactions following vaccination [94]. For these reasons, alternatives to Freunds' adjuvants, the Montanide ('oil-in-water') adjuvants have been used in several cocktail studies summarized in Table 1 [38,45,72,95-98]. Until now, however, few studies have examined the effect of different adjuvants on cocktail vaccine efficacies $[73,92,98,99]$. Nonetheless, it is impossible to rule out the possibility that adjuvants impact the efficacy of cocktail tick vaccine antigens. 


\subsubsection{Animal Genetics}

Presumably, because of logistical constraints, tick vaccination experiments are conducted using animal models such as rabbits, mice, guinea pigs, sheep, and dogs. Often the criteria for selecting the models are (1) whether the ticks can feed on the animal model, (2) whether the animal has had prior tick exposure (discussed below), and (3) the availability of pathogen-free ticks for challenge. Another, but rarely scrutinized, factor is the animal's genetic background. Reports indicate that genetic factors can influence the animal immune response [100-103]. Moreover, the influence is shown to be high among inbred models [104-107]. Furthermore, Taussig et al. [108] demonstrated that antigenic competition varies with the genetic background of the experimental animal. Intriguingly, a similar phenomenon was observed among rabbits that were inoculated with the same recombinant glutathione S-transferase (rGST) cocktail tick antigen [109]. In this study, two rabbits of each group were inoculated as follows: group 1, cocktail 1 made of rGSTs from Rhipicephalus decoloratus (rGST-Rd), Amblyomma variegatum (rGST-Av) [45] Haemaphysalis longicornis (rGST-Hl) [110], and group 2, with cocktail 2 made of rGST-Av and rGST-Rd. Note, however, in that report, the genetic background of the rabbits was not known. Based on this study, it is possible that the potential of the cocktail tick vaccine antigens could be underestimated; hence, the vaccines are not further investigated.

Additionally, the question of whether prior animal tick exposure (which can lead to bovine resistance to ticks) may influence the efficacy of candidate cocktail vaccines. Although all tick species induce cattle resistance, the phenomenon is more pronounced when cattle are exposed to 'one-host' tick species such as $R$. decoloratus and/or R. microplus. In fact, vaccination studies against 'one-host' ticks can only be conducted using cattle. Specifically, these ticks complete their entire life cycle on the same cow or bull. One-host tick species evolved on Bos indicus breeds of cattle which, as such, are capable of tolerating ticks at lower numbers compared to tick susceptible Bos taurus breeds [110]. For this reason, in tropical and sub-tropical regions of the world, Bos indicus $\times$ Bos taurus breeds are used to control tick populations. Consequently, these cross breeds continue to show traits of widespread tick resistance [111]. These findings emphasize the urgent need for research to identify genetic markers to select cattle for tick resistance particularly in crossbreeds reviewed by Tabor et al. [112]. In addition, often cattle tick vaccine trials are undertaken in susceptible Bos taurus breeds, it is rare that trials are undertaken using several different breeds or crossbreeds. It is possible that variable responses to vaccine candidates will also be observed in cattle, such as a recent report using subolesin antigens in Bos indicus vs. a crossbreed [113] (see Table 1).

Interestingly, Piper et al. [111] indicated that ELISA screening using tick fractions showed low IgG responses from serum from tick exposed R. microplus resistant cattle. This has also been observed in our tick vaccine research, where different proteins induced high IgG responses in susceptible cattle breeds, but these did not control ticks following infestation challenge [74].

Finally, considering that cattle trials are very expensive, in some instances, antibody responses are first measured in sheep as a cheaper model than cattle [114]. The results, however, do not always translate to how the antigens will behave in cattle as confirmed by Bm86 cocktail vaccination studies in sheep and cattle [73]. Given these potential limitations, it is worth taking into account the major histocompatibility complex (MHC) gene diversity among different cattle breeds when considering cocktail vaccines. MHCs are groups of genes that code for proteins found on the surfaces of cells that help the immune system recognize foreign substances. There are two types of genes coding for the proteins-MHC class I molecules and MHC class II molecules that are directly involved in the antigen presentation. These genes are highly polymorphic and are less defined in species such as cattle. Several tick immunological studies have demonstrated that different MHC2 classes are responsible for tick resistance or susceptibility $[115,116]$; however, these findings have not been used to inform vaccine research directly. Some researchers have tried to predict B cell and/or T cell binding epitopes in putative tick vaccine candidates (reviewed by Lew-Tabor and Rodriguez Valle [6,117]); however, the tools for these bioinformatics predictions for use in non-human hosts have yet to be developed. 
It is likely that these factors could still be hindering the success of researchers in formulating cocktail tick vaccine with high immune potency.

\subsection{Subunit Protein Expression System}

Since the inception of tick vaccines against Ixodid [26] and Argasid [28] ticks, numerous antigens have been identified [18-22]. and the respective proteins (tick antigens) have been expressed in different systems. The commonly used systems include mammalian, yeast, bacterial-based, and insect cells [118-120], all investigated toward obtaining immunogenic vaccines (see also Table 1). The rationale is that the conformational structure influences vaccine immunogenicity. Particularly, expression of proteins in a bacterial system could lead to the formation of misfolded proteins which lack the conformational epitopes that induce antibody production [121]. On the contrary, although Bm86 protein expressed in E. coli is less immunogenic than the Bm86 expressed in yeast [18] or insect [98] cells, no significant reduction in vaccine efficacy is reported [122]. The E. coli expressed Bm86 'glycoprotein' lacked glycosylation compared to yeast expressed Bm86 [123,124]. Although bacterial expression presents numerous advantages over other systems [125], it should be noted that bacterial-expressed proteins are not likely to have the same biological activity as the corresponding native eukaryotic tick protein. Currently, it is evident that the bacterial-based systems (particularly E. coli cells) is the preferred system for expressing subunit tick proteins (Table 1). However, this choice may simply be the preferential use of bacteria in these studies. In addition, until now there is no benchmark system for expressing anti-tick vaccines [126], with 'anecdotal evidence' indicating that eukaryotic expression systems are better than prokaryotic.

Considering that the concept of cocktail vaccines calls for the application of at least two single or chimeric proteins antigens, there is a possibility that conformational structure-alteration of E. coli-expressed cocktail-antigens affects the immunogenicity of cocktail vaccines. Although cocktail vaccines based on single antigens have been tested (Table 1), reports of chimeric-based vaccines are scarce. The scarcity of reports on chimeric-based cocktail vaccines is not an indicator that tick-researchers have not made chimeras; rather, it could suggest that tick researchers are still facing challenges in expressing effective chimeric-tick vaccines. Hypothetically, introducing large genetic material (chimera) into E. coli (the most commonly used system for expressing tick proteins) still limits the expression of chimeric-tick vaccines. This view is based on evidence that methods (for instance, electroporation) for delivering genetic material can lead to, cell lysis, high cell mortality, low transformation efficiency, and low throughput [127-129]. Another widely used method for transformation is heat shock which can only deliver small sized plasmids [130]. A study comparing the effectiveness of different expression platforms to deliver chimeric tick vaccines would be beneficial. However, this potentially brings large costs to researchers associated with large animal trials and also explains why perhaps such studies have yet to be conducted or published.

\section{Can We Enhance the Efficacy of Cocktail Vaccines?}

In spite of the aforementioned potential limitations, this section discusses the probable approaches of enhancing cocktail tick vaccine antigens.

\subsection{Cocktail Antigen Selection}

In principle cocktail tick vaccines are formulated with the goals of $(\mathrm{A})$ enhancing the protection efficacy against a particular tick species, (B) increasing the tick species host protection range, (C) inducing protection against different stages of tick development, or (D) interfering with tick-borne pathogen transmission and the tick biological parameters. Therefore, tick-borne pathogen antigens, antigens from different tick stages, and from different tick species could be used to formulate cocktail vaccines [6]. However, antigenic competition is likely to occur between the cocktail antigens. Then, the question remains: which antigens should be used to formulate cocktail vaccines? For instance, recently, it was illustrated a probable approach for selecting cocktail rGST antigens (Table 1) [45]. It should 
be noted that the antigens were selected based on the anti-rGST serum cross-reactivity rGSTs from five different tick species. Subsequently, cocktail 1 ( $R$. decoloratus rGST-Rd, A. variegatum rGST-Av and H. longicornis rGST-Hl) and cocktail 2 (rGST-Rd and rGST-Av) were combined and investigated in rabbits against Rhipicephalus sanguineus [45], and R. appendiculatus infestation [109]. Previously, Parizi et al. [95] investigated a cocktail vaccine that was composed of rGST-Hl from H. longicornis [110], vitellin-degrading cysteine endopeptidase (VTDCE) [131], and Boophilus yolk pro-cathepsin (BYC) [132] from R. microplus. Although the cocktail vaccination experiments were performed in different models (rabbits and cattle respectively), a reduction of antibodies against the cocktail antigens was noted in both studies. By contrast, reduction among the related rGST cocktail of related antigens $[45,109]$ was less than that shown with the cocktail of non-related antigens [95]. However, no direct comparison could be made regarding the efficacy of the rGST cocktails $[45,95,109]$ as the experiments were conducted against different tick species. Nevertheless, the impact induced on the biological parameters of R. appendiculatus [109] was substantively significant compared to $R$. sanguineus [45].

Along these lines, Hammerl et al. [133] reported that heterologous anti-cocktail serum (induced against related but not identical antigens) consisted of diverse antibodies that could cross-react against both the cocktail antigens and other weak immunogens. In fact, antiserum cross-reactivity is suggested to be fundamental in inducing heterologous adaptive immunity, a phenomenon where a pathogen vaccine antigen induces immune-protection against non-related pathogens [134]. For instance, the implication of heterologous immunity in the control of human infectious pathogens has been extensively discussed [135-137]. Therefore, it is likely that heterologous cocktail tick vaccine (with homologous, but not identical antigens) could induce lower antigenic competition and a higher cross-reactive adaptive immunity than the cocktails made-up of non-related, or non-identical antigens. Additionally, the cross-reactive adaptive immunity could be further exploited in the search for broad-spectrum cocktail tick-vaccine antigens.

\subsection{Chimera-Based Cocktail Tick Vaccines}

Chimeras are structural-based hybrid vaccines that are composed by fusing two or more antigenic fragments. In this context, antigen nucleotide coding sequences are fused using a linker sequence and inserted into an expression plasmid. This approach has been investigated for the control of ticks and tick-borne pathogens [138-140]. It should be noted that the chimera vaccines were constituted based on the tick antigen open reading frame (ORF) and a pathogen protein-coding sequence. Until now however, the reports on chimera vaccines based on several tick antigen nucleotide coding sequences remain scarce with no approaches leading to commercialization. Nonetheless, it is feasible that chimeric tick sequence constructs can be expressed as subunit/ recombinant vaccine antigens. Indeed, to limit the logistical constraints, expression can be performed in E. coli or yeast. However, as predicted with subunit vaccines the expressed protein is likely to be misfolded and less immunogenic [121]. These limitations could be addressed in two ways discussed hereafter. However, for reasons described (3.2), it is probable that in both approaches researchers are likely to encounter challenges in delivering large chimeric plasmids in E. coli (the commonly used system for tick protein expression) which will hinder success in chimeric-cocktail antigen expression. To avert this challenge researchers ought to consider using the cell penetration peptide mediated transformation method for inserting chimeric plasmids [141].

Hypothesis 1. Construction of epitope-based chimera vaccines.

Evidence indicates that epitope-based synthetic peptide vaccines can independently, induce immune protection against ticks [74,142,143]. Consequently, the possibility of using epitope-based cocktail vaccines has been demonstrated [60], although there was no enhanced vaccine efficacy (Table 1). Rather, on combining the epitope-synthetic peptides, there was a decrease in the humoral response which could have affected the overall efficacy. Certainly, the potential 
causes earlier discussed herein could apply to this phenomenon. For instance, evidence shows that an epitope-based cocktail may also exhibit immunological limitations such as antigenic competition $[144,145]$. Nevertheless, the factors proposed hereafter toward enhancing the efficacy of cocktail tick vaccines could suffice. Despite the fact that synthetic-peptide-based vaccines present numerous benefits, these vaccines are also associated with high production costs which limits their applications within livestock industries [146]. Therefore, designing epitope-based chimeric vaccines is one of the ways of limiting the production costs. Although the concept of epitope-chimera vaccines has been exploited toward the control of ticks [147], reports of enhanced protection under field conditions remain scarce. This could be attributed to the fact that there are still no standard pipelines for predicting tick vaccine epitopes [148-150].

\section{Hypothesis 2. Chimera-based DNA vaccines.}

Chimeric constructs could be delivered as DNA vaccines. Indeed, the merits and demerits of DNA vaccines have been discussed extensively [151]. The concept of DNA tick-vaccines has been demonstrated $[152,153]$. Similarly, chimeric DNA constructs could be combined to formulate cocktail vaccines, however, this could also trigger undesired immunological reactions such as antigenic competition [154]. Therefore, to ensure efficacy of chimera-based vaccines, the factors discussed hereafter should be taken into account.

\subsection{Conjugate Vaccines}

Based on the evidence that native protein extracts induce an acquired resistance against ticks [26], various tick recombinant antigens have been identified [18-21]. With the exception of Bm86 [34,35], few antigens have shown potential to be applied under field conditions. Generally, subunit antigens confer a lower immune response compared to the native protein extracts. This could be attributed to the fact that, unlike subunit vaccine proteins, native proteins contain post-transcriptional modifications such as glycosylation $[155,156]$. In contrast, it seems that some subunit antigens contain glycosylated and/or non-glycosylated determinants. For instance, the Bm86 protein is a glycosylated antigen that was isolated from $R$. microplus [157]. In addition, the antigen was shown to induce protection against $R$. microplus [98] and other tick species [36]. Intriguingly, the Bm86 protein expressed in E. coli was shown to induce a lower immune response than the protein expressed in insect cells [98] and Pichia pastoris [47]. This low immunogenicity could be attributed to the fact that the proteins expressed in E. coli are not glycosylated [158]. In fact, Willadsen and McKenna [122], illustrated that antibodies induced against the Bm86 protein expressed in E. coli could not react against the native gut protein extract.

Evidence shows that when used independently, polysaccharide antigenic determinants induce low immunogenicity $[159,160]$. Furthermore, it was illustrated that when a polysaccharide is conjugated to a protein carrier, its immunogenicity is enhanced [160]. This concept has since been used to enhance the protective efficacy against infectious human pathogens $[161,162]$. The probable benefit is that the conjugate vaccine triggers a dual immune response. Specifically, the polysaccharide and protein carrier induce a B cell and T cell immune responses respectively which results in increased B cell activation and hence antibody production [163,164]. Given that glycoproteins are key in the tick-pathogen interaction [165,166], and in the induction of host acquired immune tick resistance [18,157], a cocktail of glycosylated and non-glycosylated tick-antigens could enhance vaccine protection efficacy.

\subsection{Modification of the Cocktail Vaccination Protocols}

Similar to traditional vaccines, anti-tick vaccination is commonly based on the principle that the animal immune system is primed with the tick antigen and subsequently boosted with the same antigen. Specifically, this is referred to as the homologous prime-boost immunization strategy [167]. Despite the fact that this immunization strategy is also used with cocktail tick vaccines, there are no reports on 
whether the approach potentiates the antigens. It is also not known whether the interval between the cocktail vaccine doses is sufficient to limit the interference of the boost dose-response with the primary immune germinal cells. For instance, in humans, single vaccine doses are administered at an interval of four or eight weeks [168]. By contrast, tick vaccine antigens are often administered at intervals of 2-3 weeks. Given that the anticipated potential of the cocktail antigens is yet to be fully exploited using the homologous prime-boost vaccination, it is worth investigating the heterologous prime-boost strategy. However, vaccination using the latter approach may require different delivery systems [169]. For instance, the heterologous strategy may involve priming with the host with a DNA-based antigen and boosting with a subunit or peptide antigen. In fact, recently, Hassan et al. [153] demonstrated the potential of enhancing a tick vaccine using the DNA prime dose and a synthetic peptide.

While undertaking cocktail vaccine antigen experiments, it is worth asking the following questions: (A) what is the best immunization strategy? (B) what is the prime boosting antigen? (C) how many boost doses should be administered? (D) what is the best site for cocktail vaccine inoculation? Evidence, for instance, indicates that inoculation of multiple antigens at the same site induces antigenic competition $[80,170]$. (E) could adjuvants play a role in the cocktail vaccine antigen efficacy? For example, Brown et al. [91] demonstrated that a salivary gland protein in FIA was more immunogenic than in FCA; however, this is contradicted by the reports of Imamura et al. using different salivary protein antigens (Table 1).

\section{Conclusions}

The potential limitations and probable ways discussed herein toward the enhanced efficacy of cocktail tick vaccines are by no means the only factors. For instance, alternative vaccine delivery systems (VDSs) such as immune-stimulating complexes (ISCOMs), liposomes, and nanoparticles [90] are yet to be exploited not just with the formulation of cocktail anti-tick vaccines but with single anti-tick vaccines as well. Effective vaccine delivery systems are a necessity, especially when antigens are rapidly degraded during inoculation and hence not efficiently transported or presented to the immune system. Nevertheless, the factors discussed in this review merit experimental studies, not just in validating the previous cocktail vaccines but also in formulating novel cocktail vaccines against Ixodid and Argasid ticks. Calculating the protection efficacy of cocktail vaccines may require initial screening of the independent single antigens. Based on the evidence illustrated herein, it is no longer a question as earlier raised by Willadsen [25] that the concept of cocktail antigens is a valid hypothesis; the hope of sustaining enhanced efficacy has been substantiated [96]. Additionally, using an in vitro tick feeding with cocktail vaccine antibodies, Trentelman et al. [66] demonstrated that anti-Bm86 antibodies attacked the tick gut, whereas anti-subolesin antibodies attacked tick salivary glands and the rectal sac epithelium. This illustrates potential synergistic benefits of using cocktail tick vaccines. Ultimately, there is cause for optimism that cocktail antigens can boost the effort toward controlling ticks under field conditions. 
Table 1. Summary of single and cocktail efficacies from in vivo tick vaccine trials.

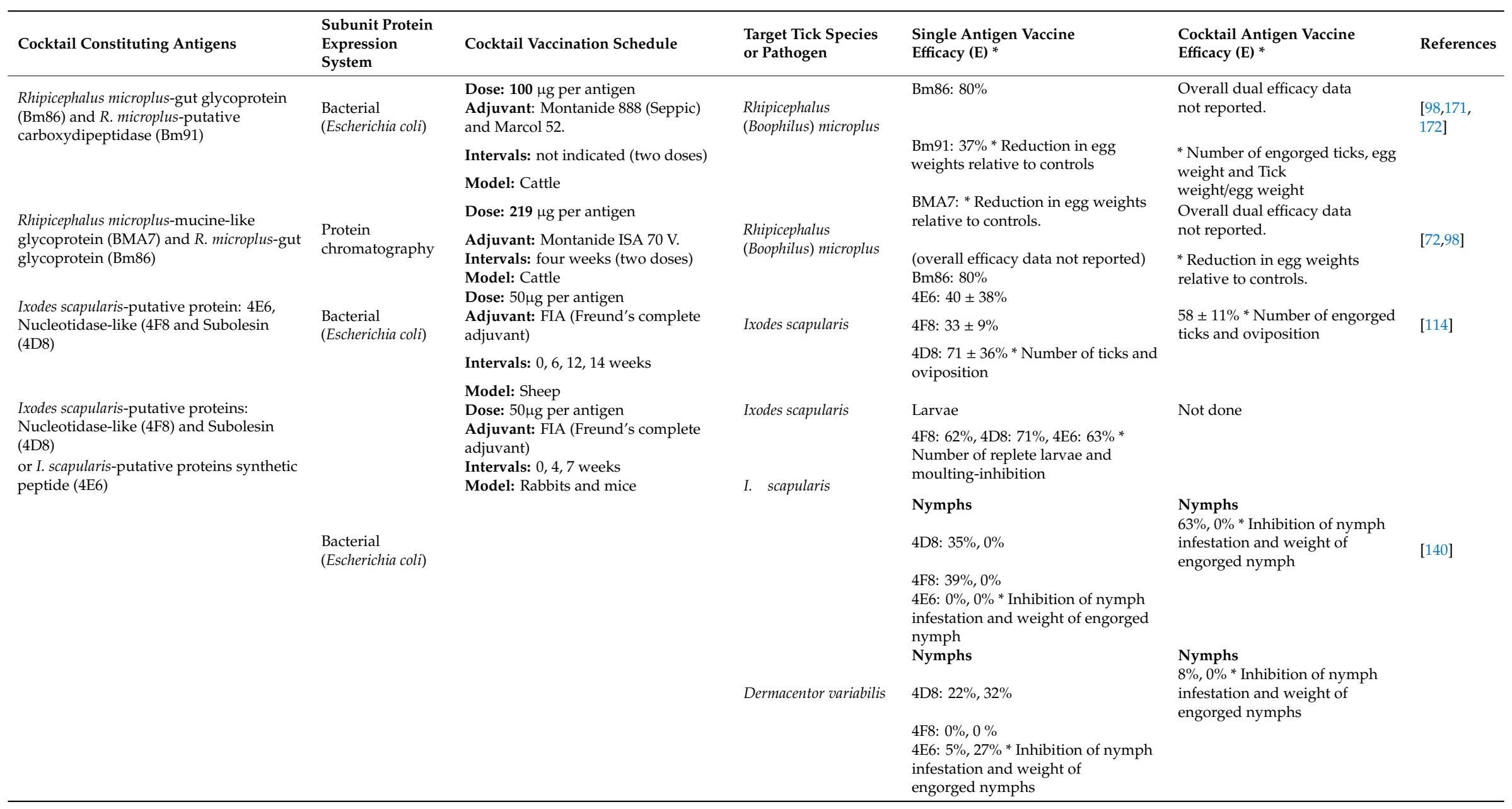


Table 1. Cont.

\begin{tabular}{|c|c|c|c|c|c|c|}
\hline Cocktail Constituting Antigens & $\begin{array}{l}\text { Subunit Protein } \\
\text { Expression } \\
\text { System }\end{array}$ & Cocktail Vaccination Schedule & $\begin{array}{l}\text { Target Tick Species } \\
\text { or Pathogen }\end{array}$ & $\begin{array}{l}\text { Single Antigen Vaccine } \\
\text { Efficacy (E) * }\end{array}$ & $\begin{array}{l}\text { Cocktail Antigen Vaccine } \\
\text { Efficacy (E) * }\end{array}$ & References \\
\hline & & & & Nymphs & Nymphs & \\
\hline & & & $\begin{array}{l}\text { Amblyomma } \\
\text { americanum }\end{array}$ & 4D8: $17 \%, 3 \%$ & $12 \%, 16 \%$ & \\
\hline & & & & $4 \mathrm{~F} 8: 9 \%, 1 \%$ & $\begin{array}{l}{ }^{*} \text { Inhibition of nymph infestation } \\
\text { and weight of engorged nymphs }\end{array}$ & \\
\hline & & & & $\begin{array}{l}\text { 4E6: } 29 \%, 0 \% * \text { Inhibition of nymph } \\
\text { infestation and weight of } \\
\text { engorged nymphs }\end{array}$ & & \\
\hline $\begin{array}{l}\text { Rhipicephalus appendiculatus serpin-1 } \\
\text { (rRAS-1), serpin-2 (rRAS-2) }\end{array}$ & $\begin{array}{l}\text { Bacterial } \\
\text { (Escherichia coli) }\end{array}$ & $\begin{array}{l}\text { Dose: } 500 \mu g \text { per antigen } \\
\text { Adjuvant: Freund's complete } \\
\text { adjuvant (FIA) (Priming dose), and } \\
\text { Freund's incomplete adjuvant (FAC) } \\
\text { (booster dose) } \\
\text { Intervals: } 14 \text { days (three doses) } \\
\text { Model: Cattle }\end{array}$ & $\begin{array}{l}\text { Rhipicephalus } \\
\text { appendiculatus }\end{array}$ & (Not done) & $\begin{array}{l}61.4 \% * \text { Reduction in nymph } \\
\text { engorgement and } 28 \text { (male) and } \\
43 \% \text { (female) }{ }^{*} \text { increased } \\
\text { tick mortality }\end{array}$ & [99] \\
\hline \multirow{2}{*}{$\begin{array}{l}\text { Rhipicephalus appendiculatus-protein: } \\
\text { serpin-3 (rRAS-3), serpin-4 }(\text { rRAS- } 4 \text { ) and a } \\
\text { 36kDa immuno-dominant protein } \\
\text { (rRIM36) }\end{array}$} & \multirow[b]{2}{*}{$\begin{array}{l}\text { Bacterial } \\
\text { (Escherichia coli) }\end{array}$} & Dose: $300-350 \mu \mathrm{g}$ per antigen & $\begin{array}{l}\text { Rhipicephalus } \\
\text { appendiculatus }\end{array}$ & & $39.5 \% *$ uninfected-tick mortality & \\
\hline & & $\begin{array}{l}\text { Adjuvants: Freund's complete } \\
\text { adjuvant (FCA) (Priming dose) and } \\
\text { Freundś incomplete adjuvant (FIA) } \\
\text { (booster doses) } \\
\text { Intervals: } 14 \text { days (three doses) } \\
\text { Model: Cattle }\end{array}$ & Theileria parva & Note done & $\begin{array}{l}48.5 \% * \text { T. parva infected-tick } \\
\text { mortality }\end{array}$ & [92] \\
\hline \multirow{2}{*}{$\begin{array}{l}\text { Rhipicephalus microplus-5'-nucleotidase } \\
\text { (4F8) and R. microplus-gut glycoprotein } \\
\text { (Bm86) }\end{array}$} & $\begin{array}{l}\text { 4F8: Bacterial } \\
\text { (Escherichia coli) }\end{array}$ & \multirow{2}{*}{$\begin{array}{l}\text { Dose: } 80 \text { and } 100 \mu \mathrm{g} \text { per antigen in the } \\
\text { respective models } \\
\text { Adjuvant: ISA50, QuilA and ISA773 } \\
\text { (Seppic) }\end{array}$} & \multirow{2}{*}{$\begin{array}{l}\text { Rhipicephalus } \\
\text { microplus }\end{array}$} & $\begin{array}{l}\text { 4F8: Overall efficacy data } \\
\text { not reported }\end{array}$ & \multirow[t]{2}{*}{$\begin{array}{l}\text { Overall efficacy data } \\
\text { not reported. }\end{array}$} & [73] \\
\hline & $\begin{array}{l}\text { Bm86 (Yeast: } \\
\text { Pichia pastoris) }\end{array}$ & & & Bm86: 81\% & & \\
\hline \multirow{5}{*}{$\begin{array}{l}\text { Haemaphysalis longicornis-Recombinant } \\
\text { Glutathione-S. transferase (rGST-HI), } \\
\text { Rhipicephalus microplus-vitellin-degrading } \\
\text { cysteine endopeptidase (VTDCE) and } R \text {. } \\
\text { microplus-Boophilus Yolk Cathepsin (BYC) }\end{array}$} & \multirow{5}{*}{$\begin{array}{l}\text { Bacterial } \\
\text { (Escherichia coli) }\end{array}$} & Model: Sheep and cattle & \multirow{5}{*}{$\begin{array}{l}\text { Rhipicephalus } \\
\text { microplus }\end{array}$} & $\begin{array}{l}{ }^{*} \text { Number of engorged ticks, egg } \\
\text { weight and tick weight/egg weight }\end{array}$ & $\begin{array}{l}\text { * Number of engorged ticks, egg } \\
\text { weight and tick }\end{array}$ & \\
\hline & & Dose: $200 \mu \mathrm{g}$ per antigen & & rGST-HI: $57 \%$ & $51.3-61.6 \%$ & \\
\hline & & $\begin{array}{l}\text { Adjuvant: Montanide } 888 \text { and } \\
\text { Marcol } 52\end{array}$ & & VTDCE: $21 \%$ & ${ }^{*}$ Number of engorged ticks & {$[38,95,173$,} \\
\hline & & Intervals: three weeks (three doses) & & $\begin{array}{l}\text { BYC: } 25.24 \% * \text { Number of of } \\
\text { engorged ticks, egg weight and } \\
\text { larva-emergence }\end{array}$ & & \\
\hline & & Model: Cattle & & & & \\
\hline
\end{tabular}


Table 1. Cont

\begin{tabular}{|c|c|c|c|c|c|c|}
\hline Cocktail Constituting Antigens & $\begin{array}{l}\text { Subunit Protein } \\
\text { Expression } \\
\text { System }\end{array}$ & Cocktail Vaccination Schedule & $\begin{array}{l}\text { Target Tick Species } \\
\text { or Pathogen }\end{array}$ & $\begin{array}{l}\text { Single Antigen Vaccine } \\
\text { Efficacy }(\mathrm{E}){ }^{*}\end{array}$ & $\begin{array}{l}\text { Cocktail Antigen Vaccine } \\
\text { Efficacy }(\mathrm{E}) *\end{array}$ & References \\
\hline $\begin{array}{l}\text { Rhipicephalus microplus- gut glycoprotein } \\
\text { (Bm86) and Ixodes scapularis-Subolesin } \\
\text { (4D8) }\end{array}$ & $\begin{array}{l}\text { Bacterial } \\
\text { (Escherichia coli) }\end{array}$ & $\begin{array}{l}\text { Dose: } 100 \mu \text { g each antigen } \\
\text { Adjuvant: Montanide ISA50V2 } \\
\text { (Seppic France). } \\
\text { Intervals: four weeks (three doses) } \\
\text { Model: Cattle }\end{array}$ & $\begin{array}{l}\text { Rhipicephalus } \\
\text { microplus } \\
\text { Rhipicephalus } \\
\text { annulatus }\end{array}$ & $\begin{array}{l}\text { Bm86: } 79 \% \\
\text { 4D8: } 58 \pm 11 \% * \text { Number of } \\
\text { engorged ticks and oviposition }\end{array}$ & $\begin{array}{l}99 \% * \text { Number of engorged ticks, } \\
\text { oviposition and larval emergence }\end{array}$ & [96] \\
\hline \multirow{3}{*}{$\begin{array}{l}\text { Ixodes ricinus-Recombinant gut } \\
\text { glycoproteins: 86-1 (rIr86-1) and 86-2 } \\
\text { (Ir86-2) }\end{array}$} & \multirow{3}{*}{$\begin{array}{l}\text { Bacterial } \\
\text { (Escherichia coli) }\end{array}$} & Dose: $50 \mu \mathrm{g}$ per antigen & \multirow{3}{*}{ Ixodes ricinus } & rIr86-1 and Ir86-2 & $\begin{array}{l}\text { Overall efficacy data } \\
\text { not reported. }\end{array}$ & \multirow{3}{*}{ [93] } \\
\hline & & $\begin{array}{l}\text { (FCA) (Priming dose) and Freundś } \\
\text { incomplete adjuvant (FIA) } \\
\text { (booster doses) }\end{array}$ & & Overall efficacy data not reported. & $\begin{array}{l}* \text { Number of engorged ticks } \\
\text { and oviposition }\end{array}$ & \\
\hline & & Intervals: 3 weeks ( 3 doses) & & $\begin{array}{l}\text { * Number of engorged ticks } \\
\text { and oviposition }\end{array}$ & & \\
\hline \multirow{3}{*}{$\begin{array}{l}\text { Rhipicephalus appendiculatus histamine } \\
\text { binding proteins (HBPM, HBPF1, HBPF2), } \\
\text { R. appendiculatus-cement cone full-protein } \\
\text { (TRPFL) and truncated-TRP protein } \\
\text { (TRP18-89) } \\
\text { R. appendiculatus-subolesin homologue } \\
\text { (4D8), and Theileria parva sporozoite } \\
\text { antigen (p67C) }\end{array}$} & \multirow{3}{*}{$\begin{array}{l}\text { Bacterial } \\
\text { (Escherichia coli) }\end{array}$} & $\begin{array}{l}\text { Model: Rabbits } \\
\text { Dose: } 50 \mu \mathrm{g} \text { per antigen }\end{array}$ & Rhipicephalus & \multirow{3}{*}{ Not done } & $\begin{array}{l}\text { Overall efficacy data } \\
\text { not reported. }\end{array}$ & \multirow{3}{*}{ [97] } \\
\hline & & Adjuvant: Montanide ISA $50 \mathrm{~V}$. & appendiculatus & & $\begin{array}{l}{ }^{*} \text { Number of engorged ticks and } \\
\text { egg weight }\end{array}$ & \\
\hline & & $\begin{array}{l}\text { Intervals: four weeks (three doses) } \\
\text { Model: Cattle }\end{array}$ & Theileria parva & & & \\
\hline $\begin{array}{l}\text { antigen (p67C) } \\
\text { Rhipicephalus microplus-protein: } 39 \text { (Rm39), } \\
180 \text { (Rm180), } 239 \text { (Rm239) and } 76 \text { (Rm76) }\end{array}$ & $\begin{array}{l}\text { Bacterial } \\
\text { (Escherichia coli) }\end{array}$ & $\begin{array}{l}\text { Dose: } 100 \mu \mathrm{g} \text { and } 25 \mu \mathrm{g} \\
\text { Adjuvant: Aluminium hydroxide } \\
\text { Intervals: three weeks (three doses) } \\
\text { Model: Cattle }\end{array}$ & $\begin{array}{l}\text { Rhipicephalus } \\
\text { (Boophilus) microplus }\end{array}$ & Note done & $\begin{array}{l}73.2 \% * \text { Number of engorged } \\
\text { ticks, oviposition and } \\
\text { larval emergence }\end{array}$ & [117] \\
\hline $\begin{array}{l}\text { Amblyomma variegatum-Recombinant } \\
\text { Glutathione-S-transferase (rGST-Av) and } \\
\text { Rhipicephalus decoloratus-Recombinant } \\
\text { Glutathione-S-transferase (rGST-Rd) }\end{array}$ & $\begin{array}{l}\text { Bacterial } \\
\text { (Escherichia coli) }\end{array}$ & $\begin{array}{l}\text { Dose: } 100 \mu g \text { per antigen } \\
\text { Adjuvant: Montanide } 888 \text { (Seppic) } \\
\text { and Marcol } 52 \text {. } \\
\text { Intervals: } 14 \text { days (three doses) }\end{array}$ & $\begin{array}{l}\text { Rhipicephalus } \\
\text { sanguineus }\end{array}$ & Note done & $\begin{array}{l}37.27 \% * \text { Number of } \\
\text { engorged ticks }\end{array}$ & [45] \\
\hline \multirow[t]{2}{*}{$\begin{array}{l}\text { Rhipicephalus australis-peptide: } 4,6 \text { and } 7 \\
\text { conjugated with key limpet haemocyanin } \\
\text { (KLH) }\end{array}$} & \multirow[t]{4}{*}{$\begin{array}{l}\text { Chemical } \\
\text { synthesis }\end{array}$} & $\begin{array}{l}\text { Dose: } 200 \mu \mathrm{g} \\
\text { Adjuvants: Freundś complete } \\
\text { adjuvant (FCA) (Priming dose), }\end{array}$ & Rhipicephalus australis & Peptide 4-KLH 65\% & \multirow[t]{4}{*}{$\begin{array}{l}47 \% * \text { Number of engorged ticks, } \\
\text { tick number/egg weights, } \\
\text { and egg fertility }\end{array}$} & \multirow[t]{4}{*}[74]{} \\
\hline & & $\begin{array}{l}\text { Freundś incomplete adjuvant (FIA) } \\
\text { (booster doses) }\end{array}$ & & -KLH $63 \%$ & & \\
\hline \multirow{2}{*}{$\begin{array}{l}\text { (Peptide 4-KLH, Peptide-6-KLH, Peptide } \\
\text { 7-KLH) }\end{array}$} & & $\begin{array}{l}\text { Intervals: Day } 0,4,7 \text { weeks } \\
\text { (three doses) }\end{array}$ & & Peptide 7-KLH 45\% & & \\
\hline & & Model: Cattle Bos taurus Herefords & & $\begin{array}{l}{ }^{*} \text { Number of ticks, tick number/egg } \\
\text { weights, and egg fertility }\end{array}$ & & \\
\hline
\end{tabular}


Table 1. Cont

\begin{tabular}{|c|c|c|c|c|c|c|}
\hline Cocktail Constituting Antigens & $\begin{array}{l}\text { Subunit Protein } \\
\text { Expression } \\
\text { System }\end{array}$ & Cocktail Vaccination Schedule & $\begin{array}{l}\text { Target Tick Species } \\
\text { or Pathogen }\end{array}$ & $\begin{array}{l}\text { Single Antigen Vaccine } \\
\text { Efficacy }(\mathrm{E})^{*}\end{array}$ & $\begin{array}{l}\text { Cocktail Antigen Vaccine } \\
\text { Efficacy (E) } *\end{array}$ & References \\
\hline \multirow[t]{2}{*}{$\begin{array}{l}\text { Amblyomma variegatum-Recombinant } \\
\text { Subolesin (rSUB-Av), } \\
\text { Rhipicephalus appendiculatus-Recombinant } \\
\text { Subolesin (rSUB-Ra) }\end{array}$} & \multirow[t]{3}{*}{$\begin{array}{l}\text { Bacterial } \\
\text { (Escherichia coli) }\end{array}$} & $\begin{array}{l}\text { Dose: } 100 \mu \mathrm{g} \\
\text { Adjuvant: Montanide ISA50V2 } \\
\text { (Seppic France) }\end{array}$ & $\begin{array}{l}\text { Rhipicephalus } \\
\text { appendiculatus } \\
\text { Rhipicephalus } \\
\text { decoloratus }\end{array}$ & $\begin{array}{l}\text { rSUB-Ra: } 47 \%, 50 \% \text { (B. indicus) and } \\
90 \%, 89 \% \text { and } 51 \% \text { (cross-breed) } \\
\text { rSUB-Ra: } 68 \%, 58 \% \text { (B. indicus) and } \\
89 \%, 94 \% \text { and } 69 \% \text { (cross-breed) }\end{array}$ & $\begin{array}{l}92 \%, 51 \% \text { (B. indicus) and } 74 \%, \\
69 \% \text { and } 71 \% \text { (cross-breed) }\end{array}$ & \multirow[t]{3}{*}{ [113] } \\
\hline & & Interval: 30 days (two doses) & $\begin{array}{l}\text { Amblyomma } \\
\text { variegatum }\end{array}$ & $\begin{array}{l}\text { rSUB-Av: } 86 \%, 47 \% \text { (B. indicus) and } \\
83 \%, 76 \% \text { and } 72 \% \text { (cross-breed) }\end{array}$ & ${ }^{*}$ Number of engorged ticks, egg & \\
\hline $\begin{array}{l}\text { Rhipicephalus decoloratus-Recombinant } \\
\text { Subolesin (rSUB-Rd) }\end{array}$ & & $\begin{array}{l}\text { Model: Cattle (Bovis indicus and } \\
\text { cross-breed) }\end{array}$ & & $\begin{array}{l}\text { * Number of engorged ticks, egg } \\
\text { oviposition and egg fertility }\end{array}$ & oviposition and egg fertility. & \\
\hline \multirow{3}{*}{$\begin{array}{l}\text { Ornithodorus erraticus } \\
\text { midgut-epitope-based recombinant } \\
\text { proteins: chitinases (OeCHI), 60S acidic } \\
\text { ribosomal protein P0 (OeRPP0), secreted } \\
\text { protein PK-4 (OePK4) and tetraspanins } \\
\text { (TSPs = OeTSP1 + OeTSP2) }\end{array}$} & \multirow{3}{*}{$\begin{array}{l}\text { Bacterial } \\
\text { (Escherichia coli) }\end{array}$} & Dose: $100 \mu \mathrm{g}$ & $\begin{array}{l}\text { Ornithodorus erraticus } \\
\text { and }\end{array}$ & $\begin{array}{l}\text { O. erraticus: OeCHl }(30.2 \%), \\
\text { OeRPP0 }(57.5 \%), \text { OePK } 4(57.8 \%) \text { and } \\
\text { (TSPs }=\text { OeTSP1 + OeTSP2) }(56 \%)\end{array}$ & $\begin{array}{l}\text { O. erraticus: OeCHl + OeRPP0 + } \\
\text { OePK } 4 \text { + TSPs }(66.3 \%)\end{array}$ & \multirow{2}{*}{ [175] } \\
\hline & & $\begin{array}{l}\text { Adjuvant: Montanide ISA } 50 \text { V2 } \\
\text { (Seppic, France) }\end{array}$ & O. moubata & $\begin{array}{l}\text { O. moubata: OeCHl (19.6\%), } \\
\text { OeRPP0 (0\%), OePK4 (8.1\%) and } \\
\text { (TSPs = OeTSP1 + OeTSP2) (11.1\%) } \\
\text { * Reduction of: ingested blood (in } \\
\text { males, females and Nymph-3), } \\
\text { mortality (of males, females and } \\
\text { Nymph-3), moulting (of nymphs-3), } \\
\text { oviposition (females) and fertility } \\
\text { (females) }\end{array}$ & $\begin{array}{l}\text { O. moubata: OeCHl + OeRPP0 + } \\
\text { OePK } 4 \text { + TSPs }(25.6 \%)\end{array}$ & \\
\hline & & Model: rabbits & & & $\begin{array}{l}\text { * Reduction of ingested blood (in } \\
\text { males, females, and Nymph-3), } \\
\text { mortality (of males, females, } \\
\text { and Nymph-3), moulting } \\
\text { (of Nymph-3), oviposition } \\
\text { (females) and fertility (females) }\end{array}$ & \\
\hline
\end{tabular}


Author Contributions: This review was conceptualized and originally drafted by C.N.J.; Additional editing and extensive review by A.E.T. All authors have read and agreed to the published version of the manuscript.

Funding: This research received no external funding.

Acknowledgments: We are grateful to the researchers with whom we have debated over why cocktail tick-vaccines are yet to match the expectations, for it is through these discussions that we were inspired to write this review article in search of solutions.

Conflicts of Interest: The authors declare no conflict of interest.

\section{References}

1. De la Fuente, J.; Estrada-Pena, A.; Venzal, J.M.; Kocan, K.M.; Soneshine, D.E. Overview: Ticks as vectors of pathogens that cause disease in humans and animals. Front. Biosci. 2008, 13, 6938-6946. [CrossRef] [PubMed]

2. Brites-Neto, J.; Duarte, K.M.; Martins, T.F. Tick-borne infections in human and animal population worldwide. Vet. World 2015, 8, 301-315. [CrossRef] [PubMed]

3. Horak, I.G.; Camicas, J.L.; Keirans, J.E. The argasidae, ixodidae and nuttalliellidae (acari: Ixodida): A world list of valid tick names. Exp. Appl. Acarol. 2002, 28, 27-54. [CrossRef]

4. McLeod, R.; Kristjanson, P. Economic impact of ticks and tick-borne diseases to livestock in Africa, Asia and Australia. In Report to the International Livestock; Research Institute: Nairobi, Kenya, 1999.

5. De Castrol, J.J. Sustainable tick and tick-borne disease control in livestock improvement in developing countries. Vet. Parasitol. 1997, 71, 77-97. [CrossRef]

6. Lew-Tabor, A.E.; Rodriguez Valle, M. A review of reverse vaccinology approaches for the development of vaccines against ticks and tick borne diseases. Ticks Tick Borne Dis. 2015, 7, 1236-1237. [CrossRef]

7. Muhanguzi, D.; Byaruhanga, J.; Amanyire, W.; Ndekezi, C.; Ochwo, S.; Nakamwesiga, J.; Mwiine, F.N.; Tweyongyere, R.; Fourie, J.; Madder, M.; et al. Invasive cattle ticks in East Africa: Morphological and molecular confirmation of the presence of Rhipicephalus microplus in south-eastern Uganda. Parasites Vectors 2020, 13, 165. [CrossRef]

8. Kamani, J.; Apanaskevich, D.A.; Gutiérrez, R.; Nachum-Biala, Y.; Baneth, G.; Harrus, S. Morphological and molecular identification of Rhipicephalus (Boophilus) microplus in Nigeria, West Africa: A threat to livestock health. Exp. Appl. Acarol. 2017, 73, 283-296. [CrossRef]

9. Adakal, H.; Biguezoton, A.; Zoungrana, S.; Courtin, F.; de Clercq, E.M.; Madder, M. Alarming spread of the Asian cattle tick Rhipicephalus microplus in West Africa-another three countries are affected: Burkina Faso, Mali and Togo. Exp. Appl. Acarol. 2013, 61,383-386. [CrossRef]

10. Silatsa, B.A.; Simo, G.; Githaka, N.; Mwaura, S.; Kamga, R.M.; Oumarou, F.; Keambou, C.; Bishop, R.P.; Djikeng, A.; Kuiate, J.R.; et al. A comprehensive survey of the prevalence and spatial distribution of ticks infesting cattle in different agro-ecological zones of Cameroon. Parasite Vectors 2019, 12, 489. [CrossRef]

11. Gaudreault, N.N.; Madden, D.W.; Wilson, W.C.; Trujillo, J.D.; Richt, J.A. African swine fever virus: An emerging DNA arbovirus. Front. Vet. Sci. 2020, 7, 215. [CrossRef]

12. Abbas, R.Z.; Zaman, M.A.; Colwell, D.D.; Gilleard, J.; Iqbal, Z. Acaricide resistance in cattle ticks and approaches to its management: The state of play. Vet. Parasitol. 2014, 203, 6-20. [CrossRef] [PubMed]

13. Rodriguez-Vivas, R.I.; Jonsson, N.N.; Bhushan, C. Strategies for the control of Rhipicephalus microplus ticks in a world of conventional acaricide and macrocyclic lactone resistance. Parasitol. Res. 2018, 117, 3-29. [CrossRef]

14. Pérez-Sánchez, R.; Oleaga, A. Acaricidal activity of fluralaner against Ornithodoros moubata and Ornithodoros erraticus argasid ticks evaluated through in vitro feeding. Vet. Parasitol. 2017, 243, 119-124. [CrossRef] [PubMed]

15. Williams, H.; Zoller, H.; Roepke, R.K.A.; Zschiesche, E.; Heckeroth, A.R. Fluralaner activity against life stages of ticks using Rhipicephalus sanguineus and Ornithodoros moubata IN in vitro contact and feeding assays. Parasites Vectors 2015, 8, 90. [CrossRef]

16. Astigarraga, A.; Oleaga-Pérez, A.; Pérez-Sánchez, R.; Encinas-Grandes, A. A study of the vaccinal value of various extracts of concealed antigens and salivary gland extracts against Ornithodoros erraticus and Ornithodoros moubata. Vet. Parasitol. 1995, 60, 133-147. [CrossRef] 
17. Graf, J.F.; Gogolewski, R.; Leach-Bing, N.; Sabatini, G.A.; Molento, M.B.; Bordin, E.L.; Arantes, G.J. Tick control: An industry point of view. Parasitology 2004, 129, 427-442. [CrossRef]

18. De la Fuente, J.; Kocan, K.M. Strategies for development of vaccines for control of Ixodid tick species. Parasite Immunol. 2006, 28, 275-283. [CrossRef]

19. Merino, O.; Alberdi, P.; Pérez de la Lastra, J.M.; de la Fuente, J. Tick vaccines and the control of tick-borne pathogens. Front. Cell Infect Microbiol. 2013, 3, 30. [CrossRef]

20. Nuttall, P.A.; Trimnell, A.R.; Kazimirova, M.; Labuda, M. Exposed and concealed antigens as vaccine targets for controlling ticks and tick-borne diseases. Parasite Immunol. 2006, 28, 155-163. [CrossRef]

21. Valle, M.R.; Guerrero, F.D. Anti-tick vaccines in the omics era. Front. Biosci. 2018, 10, 122-136. [CrossRef]

22. Díaz-Martín, V.; Manzano-Román, R.; Obolo-Mvoulouga, P.; Oleaga, A.; Pérez-Sánchez, R. Development of vaccines against Ornithodoros soft ticks: An update. Ticks Tick Borne Dis. 2015, 6, 211-220. [CrossRef] [PubMed]

23. Obolo-Mvoulouga, P.; Oleaga, A.; Manzano-Román, R.; Pérez-Sánchez, R. Evaluation of the protective efficacy of Ornithodoros moubata midgut membrane antigens selected using omics and in silico prediction algorithms. Ticks Tick Borne Dis. 2018, 9, 1158-1172. [CrossRef] [PubMed]

24. Toaleb, N.I.; Gabr, H.S.M.; Abd El-Shafy, S.; Abdel-Rahman, E.H. Evaluation of vaccine candidates purified from the adult ticks of Ornithodoros savignyi (Acari: Argasidae) and Hyalomma dromedarii (Acari: Ixodidae) against tick infestations. J. Parasit. Dis. 2019, 43, 246-255. [CrossRef] [PubMed]

25. Willadsen, P. Antigen cocktails: Valid hypothesis or unsubstantiated hope? Trends Parasitol. 2008, 24, 164-167. [CrossRef]

26. Trager, W. Acquired immunity to ticks. J. Parasitol. 1939, 25, 57-81. [CrossRef]

27. Trager, W. Further observations on acquired immunity to the tick dermacentor variabilis say. J. Parasitol. 1939, 25, 137-139. [CrossRef]

28. Trager, W. A note on the problem of acquired immunity to argasid ticks. J. Parasitol. Res. 1940, 26, 71-74. [CrossRef]

29. Wikel, S.K. Immunomodulation of host responses to ectoparasite infestation-an overview. Vet. Parasitol. 1984, 14, 321-339. [CrossRef]

30. Wang, H.; Nuttall, P.A. Excretion of host immunoglobulin in tick saliva and detection of IgG-binding proteins in tick haemolymph and salivary glands. Parasitology 1994, 109, 525-530. [CrossRef]

31. Ackerman, S.; Clare, F.B.; McGill, T.W.; Sonenshine, D.E. Passage of host serum components, including antibody, across the digestive tract of Dermacentor variabilis (Say). J. Parasitol. 1981, 67, 737-740. [CrossRef]

32. Ben-Yakir, D.; Fox, C.J.; Homer, J.T.; Barker, R.W. Quantification of host immunoglobulin in the hemolymph of ticks. J. Parasitol. 1987, 73, 669-671. [CrossRef] [PubMed]

33. Gough, J.M.; Kemp, D.H. Localization of a low abundance membrane protein (Bm86) on the gut cells of the cattle tick Boophilus microplus by immunogold labeling. J. Parasitol. 1993, 79, 900-907. [CrossRef] [PubMed]

34. De la Fuente, J.; Almazán, C.; Canales, M.; Pérez de la Lastra, J.M.; Kocan, K.M.; Willadsen, P. A ten-year review of commercial vaccine performance for control of tick infestations on cattle. Anim. Health Res. Rev. 2007, 8, 23-28. [CrossRef] [PubMed]

35. De la Fuente, J.; Rodríguez, M.; Redondo, M.; Montero, C.; García-García, J.C.; Méndez, L.; Serrano, E.; Valdés, M.; Enriquez, A.; Canales, M.; et al. Field studies and cost-effectiveness analysis of vaccination with Gavac against the cattle tick Boophilus microplus. Vaccine. 1998, 16, 366-373. [CrossRef]

36. De Vos, S.; Zeinstra, L.; Taoufik, O.; Willadsen, P.; Jongejan, F. Evidence for the utility of the Bm86 antigen from Boophilus microplus in vaccination against other tick species. Exp. Appl. Acarol. 2001, 25, 245-261. [CrossRef]

37. De la Fuente, J.; Moreno-Cid, J.A.; Galindo, R.C.; Almazan, C.; Kocan, K.M.; Merino, O.; Perez de la Lastra, J.M.; Estrada-Peña, A.; Blouin, E.D. Subolesin/Akirin vaccines for the control of arthropod vectors and vector-borne pathogens. Transbound Emerg. Dis. 2013, 60, 172-178. [CrossRef]

38. Parizi, L.F.; Utiumi, K.U.; Imamura, S.; Onuma, M.; Ohashi, K.; Masuda, A.; da Silva Vaz, I.J. Cross immunity with Haemaphysalis longicornis glutathione S-transferase reduces an experimental Rhipicephalus (Boophilus) microplus infestation. Exp. Parasitol. 2011, 127, 113-118. [CrossRef]

39. Sabadin, G.A.; Parizi, L.F.; Kiio, I.; Xavier, M.A.; da Silva Matos, R.; Camargo-Mathias, M.I.; Githaka, N.W.; Nene, V.; da Silva Vaz, I.J. Effect of recombinant glutathione S-transferase as vaccine antigen against Rhipicephalus appendiculatus and Rhipicephalus sanguineus infestation. Vaccine 2017, 35, 6649-6656. [CrossRef] 
40. Trimnell, A.R.; Davies, G.M.; Lissina, O.; Hails, R.S.; Nuttall, P.A. A cross-reactive tick cement antigen is a candidate broad-spectrum tick vaccine. Vaccine 2005, 23, 329-4341. [CrossRef]

41. Geraci, N.S.; Spencer Johnston, J.; Paul Robinson, J.; Wikel, S.K.; Hill, C.A. Variation in genome size of argasid and ixodid ticks. Insect Biochem. Mol. Biol. 2007, 37, 399-408. [CrossRef]

42. Gulia-Nuss, M.; Nuss, A.B.; Meyer, J.M.; Sonenshine, D.E.; Roe, R.M.; Waterhouse, R.M.; Sattelle, D.B.; de la Fuente, J.; Ribeiro, J.M.; Megy, K.; et al. Genomic insights into the Ixodes scapularis tick vector of Lyme disease. Nat. Commun. 2016, 7, 10507. [CrossRef] [PubMed]

43. Sherrard-Smith, E.; Sala, K.A.; Betancourt, M.; Upton, L.M.; Angrisano, F.; Morin, M.J.; Ghani, A.C.; Churcher, T.S.; Blagborough, A.M. Synergy in anti-malarial pre-erythrocytic and transmission-blocking antibodies is achieved by reducing parasite density. eLife 2018, 7. [CrossRef] [PubMed]

44. Darghouth, M.A.; Boulter, N.R.; Gharbi, M.; Sassi, L.; Tait, A.; Hall, R. Vaccination of calves with an attenuated cell line of Theileria annulata and the sporozoite antigen SPAG-1 produces a synergistic effect. Vet Parasitol. 2006, 142, 54-62. [CrossRef] [PubMed]

45. Ndawula, C.J.; Sabadin, G.A.; Parizi, L.F.; da Silva Vaz, I.J. Constituting a glutathione S-transferase-cocktail vaccine against tick infestation. Vaccine 2019, 37, 1918-1927. [CrossRef]

46. Galay, R.L.; Umemiya-Shirafuji, R.; Mochizuki, M.; Fujisaki, K.; Tanaka, T. RNA interference: A powerful functional analysis tool for studying tick biology and its control. In RNA Interference; Ibrokhim, Y., Ed.; IntechOpen: London, UK, 2016.

47. De la Fuente, J.; Kocan, K.M. Advances in the identification and characterization of protective antigens for recombinant vaccines against tick infestations. Expert Rev. Vaccines 2003, 2, 583-593. [CrossRef] [PubMed]

48. Artigas-Jerónimo, S.; de La Fuente, J.; Villar, M. Interactomics and tick vaccine development: New directions for the control of tick-borne diseases. Expert Rev. Proteomics 2018, 15, 627-635. [CrossRef] [PubMed]

49. Villar, M.; Marina, A.; de la Fuente, J. Applying proteomics to tick vaccine development: Where are we? Expert Rev. Proteom. 2017, 14, 211-221. [CrossRef] [PubMed]

50. Aljamali, M.N.; Hern, L.; Kupfer, D.; Downard, S.; So, S.; Roe, B.A.; Sauer, J.R.; Essenberg, R.C. Transcriptome analysis of the salivary glands of the female tick Amblyomma americanum (Acari: Ixodidae). Insect Mol. Biol. 2009, 18, 129-154. [CrossRef]

51. De la Fuente, J.; Almazán, C.; Blouin, E.F.; Naranjo, V.; Kocan, K.M. RNA interference screening in ticks for identification of protective antigens. Parasitol. Res. 2005, 96, 137-141. [CrossRef]

52. Marr, E.J.; Sargison, N.D.; Nisbet, A.J.; Burgess, S.T. RNA interference for the identification of ectoparasite vaccine candidates. Parasite Immunol. 2014, 36, 616-626. [CrossRef]

53. Lew-Tabor, A.E.; Bruyeres, A.G.; Zhang, B.; Rodriguez, V.M. Rhipicephalus (Boophilus) microplus tick in vitro feeding methods for functional (dsRNA) and vaccine candidate (antibody) screening. Ticks Tick Borne Dis. 2014, 5, 500-510. [CrossRef]

54. Antunes, S.; Couto, J.; Ferrolho, J.; Sanches, G.S.; Charrez, J.O.M.; Hernández, N.C.; Mazuz, M.; Villar, M.; Shkap, V.; de la Fuente, J.; et al. Transcriptome and proteome response of Rhipicephalus annulatus tick vector to Babesia bigemina infection. Front. Physiol. 2019, 10, 318. [CrossRef]

55. Contreras, M.; Villar, M.; de la Fuente, J. A vaccinomics approach for the identification of tick protective antigens for the control of Ixodes ricinus and Dermacentor reticulatus infestations in companion animals. Front. Physiol. 2019, 10, 977. [CrossRef]

56. Villar, M.; Ayllón, N.; Alberdi, P.; Moreno, A.; Moreno, M.; Tobes, R.; Mateos-Hernández, L.; Weisheit, S.; Bell-Sakyi, L.; de la Fuente, J. Integrated metabolomics, transcriptomics and proteomics identifies metabolic pathways affected by Anaplasma phagocytophilum infection in tick cells. Mol. Cell Proteom. 2015, 14, 3154-3172. [CrossRef]

57. Chabaud, A.G. Sur la nutrition artificielle des tiques. Ann. Parasitol. Hum. Comp. 1950, 25, 142-144. [CrossRef]

58. Rau, U.; Hannoun, C. The use of a capillary-tube technique for artificially feeding Argas reflexus reflexus ticks. Bull World Health Organ. 1968, 39, 332-333. [PubMed]

59. Willadsen, P.; Kemp, D.H.; McKenna, R.V. Bloodmeal ingestion and utilization as a component of host specificity in the tick, Boophilus microplus. Z. Parasitenkd. 1984, 70, 415-420. [CrossRef]

60. Waladde, S.M.; Young, A.S.; Morzaria, S.P. Artificial feeding of ixodid ticks. Parasitol. Today 1996, 12, $272-278$. [CrossRef] 
61. Kuhnert, F. Feeding of hard ticks in vitro: New perspectives for rearing and for the identification of systemic acaricides. ALTEX 1996, 13, 76-87. [PubMed]

62. Kröber, T.; Guerin, P.M. In vitro feeding assays for hard ticks. Trends Parasitol. 2007, 23, 445-449. [CrossRef]

63. Antunes, S.; Merino, O.; Mosqueda, J.; Moreno-Cid, J.A.; Bell-Sakyi, L.; Fragkoudis, R.; Weisheit, S.; Pérez de la Lastra, J.M.; Alberdi, P.; Domingos, A.; et al. Tick capillary feeding for the study of proteins involved in tick-pathogen interactions as potential antigens for the control of tick infestation and pathogen infection. Parasit. Vectors 2014, 7, 42. [CrossRef]

64. Kröber, T.; Guerin, P.M. An in vitro feeding assay to test acaricides for control of hard ticks. Pest. Manag. Sci. 2007, 63, 17-22. [CrossRef]

65. Gonsioroski, A.V.; Bezerra, I.A.; Utiumi, K.U.; Driemeier, D.; Farias, S.E.; da Silva Vaz, I.J.; Masuda, A. Anti-tick monoclonal antibody applied by artificial capillary feeding in Rhipicephalus (Boophilus) microplus females. Exp. Parasitol. 2012, 130, 359-363. [CrossRef]

66. Trentelman, J.J.A.; Teunissen, H.; Kleuskens, J.A.G.M.; de Crommert, J.V.; de la Fuente, J.; Hovius, J.W.R.; Schetters, T.P.M. A combination of antibodies against Bm86 and Subolesin inhibits engorgement of Rhipicephalus australis (formerly Rhipicephalus microplus) larvae in vitro. Parasit. Vectors 2019, 12, 362. [CrossRef]

67. Perner, J.; Sobotka, R.; Sima, R.; Konvickova, J.; Sojka, D.; de Oliveira, P.L.; Hajdusek, O.; Kopacek, P. Acquisition of exogenous haem is essential for tick reproduction. eLife 2016, 5. [CrossRef] [PubMed]

68. Osborne, R.W.; Mellor, P.S. Use of a silicone membrane feeding technique in the laboratory maintenance of a colony of Ornithodoros moubata. Trop Anim. Health Prod. 1985, 17, 31-38. [CrossRef] [PubMed]

69. Hokama, Y.; Lane, R.S.; Howarth, J.A. Maintenance of adult and nymphal Ornithodoros coriaceus (Acari: Argasidae) by artificial feeding through a Parafilm membrane. J. Med. Entomol. 1987, 24, 319-323. [CrossRef]

70. Schwan, E.V.; Hutton, D.; Shields, K.J.; Townson, S. Artificial feeding and successful reproduction in Ornithodoros moubata moubata (Murray, 1877) (Acarina: Argasidae). Exp. Appl. Acarol. 1991, 13, 107-115. [CrossRef]

71. Lambertz, C.; Chongkasikit, N.; Jittapalapong, S.; Gauly, M. Immune response of Bos indicus cattle against the anti-tick antigen Bm91 derived from local Rhipicephalus (Boophilus) microplus ticks and its effect on tick reproduction under natural infestation. J. Parasitol. Res. 2012, 90, 7607. [CrossRef]

72. McKenna, R.V.; Riding, G.A.; Jarmey, J.M.; Pearson, R.D.; Willadsen, P. Vaccination of cattle against the Boophilus microplus using a mucin-like membrane glycoprotein. Parasite Immunol. 1998, 20, 325-336. [CrossRef]

73. Hope, M.; Jiang, X.; Gough, J.; Josh, P.; Jonsson, N.; Willadsen, P. Experimental vaccination of sheep and cattle against tick infestation using recombinant 5'-nucleotidase. Parasite Immunol. 2010, 32, 135-142. [CrossRef] [PubMed]

74. Final Report: Cattle Vaccination Studies Using Novel Anti-Cattle Tick Antigens Developed during Beef CRC Research. Available online: https://www.mla.com.au/research-and-development/search-rd-reports/finalreport-details/Cattle-vaccination-studies-using-novel-anti-cattle-tick-antigens-developed-during-BeefCRC-research/3636 (accessed on 15 November 2017).

75. Michaelis, L. Untersuchugen über Eiweisspräzipitine. Deut. Med. Wochschr. 1902, 28, 733. [CrossRef]

76. Pross, H.F.; Eidinger, D. Antigenic competition: A review of nonspecific antigen-induced suppression. Adv. Immunol. 1974, 18, 133-168. [CrossRef]

77. Taussig, M.J.; Mozes, E.; Shearer, G.M.; Sela, M. Studies on the mechanism of antigenic competition: Analysis of competition between synthetic polypeptide antigens. Eur. J. Immunol. 1972, 2, 448-452. [CrossRef]

78. Billeskov, R.; Beikzadeh, B.; Berzofsky, J.A. The effect of antigen dose on T cell-targeting vaccine outcome. Hum. Vaccin. Immunother. 2019, 15, 407-411. [CrossRef]

79. Kim, Y.T.; Merrifield, N.; Zarchy, T.; Brody, N.I.; Siskind, G.W. Studies on antigenic competition. 3. Effect on antigenic competition on antibody affinity. Immunology 1974, 26, 943-955.

80. Brody, N.I.; Siskind, G.W. Studies on antigenic competition. J. Exp. Med. 1969, 130, 821-832. [CrossRef] [PubMed]

81. Allen, J.L.; Friedman, H. Induction of "low dose" tolerance to a bacterial somatic antigen in neonatal mice. Nat. New Biol. 1971, 233, 82-84. [CrossRef] 
82. Michallet, M.C.; Saltel, F.; Flacher, M.; Revillard, J.P.; Genestier, L. Cathepsin-dependent apoptosis triggered by supraoptimal activation of $\mathrm{T}$ lymphocytes: A possible mechanism of high dose tolerance. J. Immunol. 2004, 172, 5405-5414. [CrossRef] [PubMed]

83. Noscal, G.J. Immunological tolerance in organ transplantation. Fair prospect or fanciful folly? Circulation 1969, 39, 5-12. [CrossRef] [PubMed]

84. Sundstrom, J.B.; Cherniak, R. T-cell-dependent and T-cell-independent mechanisms of tolerance to glucuronoxylomannan of Cryptococcus neoformans serotype A. Infect. Immun. 1993, 61, 1340-1345. [CrossRef]

85. Dintzis, R.Z.; Middleton, M.H.; Dintzis, H.M. Studies on the immunogenicity and tolerogenicity of T-independent antigens. J. Immunol. 1983, 131, 2196-2203.

86. Baxter, D. Active and passive immunity, vaccine types, excipients and licensing. Occup. Med. 2007, 57, 552-556. [CrossRef]

87. Vogel, F.R. Improving vaccine performance with adjuvants. Clin. Infect. Dis. 2000, 30, 266-270. [CrossRef]

88. Awate, S.; Babiuk, L.A.; Mutwiri, G. Mechanisms of action of adjuvants. Front. Immunol. 2013, 4, 114. [CrossRef]

89. Perrie, Y.; Mohammed, A.R.; Kirby, D.J.; McNeil, S.E.; Bramwell, V.W. Vaccine adjuvant systems: Enhancing the efficacy of sub-unit protein antigens. Int. J. Pharm. 2008, 364, 272-280. [CrossRef]

90. García, A.; De Sanctis, J.B. An overview of adjuvant formulations and delivery systems. APMIS 2014, 122, 257-267. [CrossRef] [PubMed]

91. Brown, S.J.; Shapiro, S.Z.; Askenase, P.W. Characterization of tick antigens inducing host immune resistance. I. Immunization of guinea pigs with Amblyomma americanum-derived salivary gland extracts and identification of an important salivary gland protein antigen with guinea pig anti-tick antibodies. J. Immunol. 1984, 133, 3319-3325. [PubMed]

92. Imamura, S.; Konnai, S.; da Silva Vaz, I.J.; Yamada, S.; Nakajima, C.; Ito, Y.; Tajima, T.; Yasuda, J.; Simuunza, M.; Onuma, M.; et al. Effects of anti-tick cocktail vaccine against Rhipicephalus appendiculatus. Jpn. J. Vet. Res. 2008, 56, 85-98.

93. Coumou, J.; Wagemakers, A.; Trentelman, J.J.; Nijhof, A.M.; Hovius, J.W. Vaccination against Bm86 homologues in rabbits does not impair Ixodes ricinus feeding or oviposition. PLoS ONE 2015, 10, e0123495. [CrossRef]

94. Stills, H.F.J. Adjuvants and antibody production: Dispelling the myths associated with Freund's complete and other adjuvants. ILAR J. 2005, 46, 280-293. [CrossRef] [PubMed]

95. Parizi, L.F.; Reck, J.J.; Oldiges, D.P.; Guizzo, M.G.; Seixas, A.; Logullo, C.; de Oliveira, P.L.; Termignoni, C.; Martins, J.R.; da Silva Vaz, I.J. Multi-antigenic vaccine against the cattle tick Rhipicephalus (Boophilus) microplus: A field evaluation. Vaccine 2012, 30, 6912-6917. [CrossRef] [PubMed]

96. 1. WO2014154847-Vaccine against Rhipicephalus Ticks. Available online: https://patentscope.wipo.int/ search/en/detail.jsf?docId=WO2014154847 (accessed on 2 October 2014).

97. Olds, C.L.; Mwaura, S.; Odongo, D.O.; Scoles, G.A.; Bishop, R.; Daubenberger, C. Induction of humoral immune response to multiple recombinant Rhipicephalus appendiculatus antigens and their effect on tick feeding success and pathogen transmission. Parasit. Vectors 2016, 9, 484. [CrossRef]

98. Tellam, R.L.; Smith, D.; Kemp, D.H.; Willadsen, P. Vaccination against ticks. In Animal Parasite Control Utilizing Biotechnology; Yong, W.K., Ed.; CRC Press: Boca Raton, FL, USA, 1992; pp. 303-331.

99. Imamura, S.; Namangala, B.; Tajima, T.; Tembo, E.M.; Yasuda, J.; Ohashi, K.; Onuma, M. Two serine protease inhibitors (serpins) that induce a bovine protective immune response against Rhipicephalus appendiculatus ticks. Vaccine 2006, 24, 2230-2237. [CrossRef]

100. McDevitt, H.O.; Benacerraf, B. Genetic control of specific immune responses. Adv. Immunol. 1969, 11, 31-74. [CrossRef] [PubMed]

101. Kennedy, L.J.; Lunt, M.; Barnes, A.; McElhinney, L.; Fooks, A.R.; Baxter, D.N.; Ollier, W.E.R. Factors influencing the antibody response of dogs vaccinated against rabies. Vaccine 2007, 25, 8500-8507. [CrossRef]

102. Mansfield, K.L.; Burr, P.D.; Snodgrass, D.R.; Sayers, R.; Fooks, A.R. Factors affecting the serological response of dogs and cats to rabies vaccination. Vet. Rec. 2004, 154, 423-426. [CrossRef]

103. Day, M.J. Immune system development in the dog and cat. J. Comp. Pathol. 2007, 137, 10-15. [CrossRef]

104. Green, I.; Inman, J.K.; Benacerraf, B. Genetic control of the immune response of guinea pigs to limiting doses of bovine serum albumin: Relationship to the poly-L-lysine gene. Proc. Natl. Acad. Sci. USA 1970, 66, 1267-1274. [CrossRef] 
105. Nomoto, K.; Mashiba, H.; Takeya, K. Immune response against hamster erythrocytes in the low-responder mouse strains. I. Strain difference in the antibody response to primary antigenic stimulation and its disappearance after pre-sensitization with the antigen in Freund's complete adjuvant. Jpn. J. Microbiol. 1972, 16, 43-51. [CrossRef]

106. Mozes, E.; McDevitt, H.O.; Jaton, J.C.; Sela, M. The nature of the antigenic determinant in a genetic control of the antibody response. J. Exp. Med. 1969, 130, 493-504. [CrossRef]

107. Young, C.R.; O'Connor, G.P.; Griffiths, P. Genetic control of the antibody response to poly(L Tyr, L Glu)-poly(DL Ala) poly(L Lys) in mice: Analysis of (low responder x low responder)F1 hybrids. Immunology 1982, 45, 273-281. [PubMed]

108. Taussig, M.J.; Mozes, E.; Shearer, G.M.; Sela, M. Antigenic competition and genetic control of the immune response. A hypothesis for intramolecular competition. Cell Immunol. 1973, 8, 299-310. [CrossRef]

109. Ndawula, C., Jr. Vacina De Glutationa S-Transferases Como Estratégia De Controle De Carrapato. Ph.D. Thesis, Universidade Federal do Rio Grande do Sul, Porto Algere, Brazil, October 2019.

110. Da Silva Vaz, J.I.; Imamura, S.; Ohashi, K.; Onuma, M. Cloning, expression and partial characterization of a Haemaphysalis longicornis and a Rhipicephalus appendiculatus glutathione S-transferase. Insect Mol. Biol. 2004, 13, 329-335. [CrossRef]

111. Piper, E.K.; Jonsson, N.N.; Gondro, C.; Vance, M.E.; Lew-Tabor, A.; Jackson, L.A. Peripheral cellular and humoral responses to infestation with the cattle tick Rhipicephalus microplus in Santa Gertrudis cattle. Parasite Immunol. 2017, 39. [CrossRef]

112. Tabor, A.E.; Ali, A.; Rehman, G.; Garcia, G.R.; Zangirolamo, A.F.; Malardo, T.; Jonsson, N.N. Cattle tick Rhipicephalus microplus-host interface: A review of resistant and susceptible host responses. Front. Cell Infect. Microbiol. 2017, 7, 506. [CrossRef] [PubMed]

113. Kasaija, P.D.; Contreras, M.; Kabi, F.; Mugerwa, S.; de la Fuente, J. Vaccination with recombinant subolesin antigens provides cross-tick species protection in Bos indicus and crossbred cattle in Uganda. Vaccines 2020, 8 , 319. [CrossRef]

114. Almazán, C.; Kocan, K.M.; Blouin, E.F.; de la Fuente, J. Vaccination with recombinant tick antigens for the control of Ixodes scapularis adult infestations. Vaccine 2005, 23, 5294-5298. [CrossRef]

115. Untalan, P.M.; Pruett, J.H.; Steelman, C.D. Association of the bovine leukocyte antigen major histocompatibility complex class II DRB3*4401 allele with host resistance to the Lone Star tick, Amblyomma americanum. Vet. Parasitol. 2007, 145, 190-195. [CrossRef] [PubMed]

116. Rodrigues, V.; Fernandez, B.; Vercoutere, A.; Chamayou, L.; Andersen, A.; Vigy, O.; Demettre, E.; Seveno, M.; Aprelon, R.; Giraud-Girard, K.; et al. Immunomodulatory Effects of Amblyomma variegatum Saliva on bovine cells: Characterization of cellular responses and identification of molecular determinants. Front. Cell Infect. Microbiol. 2018, 7, 521. [CrossRef]

117. Maruyama, S.R.; Garcia, G.R.; Teixeira, F.R.; Brandão, L.G.; Anderson, J.M.; Ribeiro, J.M.C.; Valenzuela, J.G.; Horackova, J.; Veríssimo, C.J.; Katiki, L.M.; et al. Mining a differential sialotranscriptome of Rhipicephalus microplus guides antigen discovery to formulate a vaccine that reduces tick infestations. Parasit. Vectors 2017, 10, 206. [CrossRef]

118. Kumar, B.; Ghosh, S. Laboratory scale production of recombinant Haa86 tick protein in Pichia pastoris and in Escherichia coli system. Methods Mol. Biol. 2016, 1404, 459-482. [CrossRef]

119. Bensaci, M.; Bhattacharya, D.; Clark, R.; Hu, L.T. Oral vaccination with vaccinia virus expressing the tick antigen subolesin inhibits tick feeding and transmission of Borrelia burgdorferi. Vaccine 2012, 30, 6040-6046. [CrossRef]

120. Richardson, M.A.; Smith, D.R.; Kemp, D.H.; Tellam, R.L. Native and baculovirus-expressed forms of the immuno-protective protein BM86 from Boophilus microplus are anchored to the cell membrane by a glycosyl-phosphatidyl inositol linkage. Insect Mol. Biol. 1993, 1, 139-147. [CrossRef] [PubMed]

121. Clark, T.G.; Cassidy-Hanley, D. Recombinant subunit vaccines: Potentials and constraints. Dev. Biol. 2005, 121, 153-163.

122. Willadsen, P.; McKenna, R.V. Vaccination with 'concealed' antigens: Myth or reality? Parasite Immunol. 1991, 13, 605-616. [CrossRef] [PubMed]

123. Dertzbaugh, M.T. Genetically engineered vaccines: An overview. Plasmid 1998, 39, 100-113. [CrossRef] [PubMed] 
124. Sørensen, H.P. Towards universal systems for recombinant gene expression. Microb. Cell Fact 2010, 9, 27. [CrossRef] [PubMed]

125. Fakruddin, M.; Mohammad Mazumdar, R.; Bin Mannan, K.S.; Chowdhury, A.; Hossain, M.N. Critical factors affecting the success of cloning, expression, and mass production of enzymes by recombinant E. coli. ISRN Biotechnol. 2012, 2013, 590587. [CrossRef]

126. Schetters, T.; Bishop, R.; Crampton, M.; Kopáček, P.; Lew-Tabor, A.; Maritz-Olivier, C.; Miller, R.; Mosqueda, J.; Patarroyo, J.; Rodriguez, V.; et al. Cattle tick vaccine researchers join forces in CATVAC. Parasit. Vectors 2016, 9, 105. [CrossRef]

127. Wang, H.Y.; Bhunia, A.K.; Lu, C. A microfluidic flow-through device for high throughput electrical lysis of bacterial cells based on continuous de voltage. Biosens. Bioelectron. 2006, 22, 582-588. [CrossRef]

128. Yarmush, M.L.; Golberg, A.; Serša, G.; Kotnik, T.; Miklavčič, D. Electroporation-based technologies for medicine: Principles, applications, and challenges. Annu. Rev. Biomed. Eng. 2014, 16, 295-320. [CrossRef]

129. Kotnik, T.; Frey, W.; Sack, M.; Haberl Meglič, S.; Peterka, M.; Miklavčič, D. Electroporation-based applications in biotechnology. Trends Biotechnol. 2015, 33, 480-488. [CrossRef]

130. Yoshida, N.; Sato, M. Plasmid uptake by bacteria: A comparison of methods and efficiencies. Appl. Microbiol. Biotechnol. 2009, 83, 791-798. [CrossRef]

131. Logullo, C.; Moraes, J.; Dansa-Petretski, M.; da Silva Vaz, I.J.; Masuda, A.; Sorgine, M.H.F.; Braz, G.R.; Masuda, H.; Oliveira, P.L. Binding and storage of heme by vitellin from the cattle tick, Boophilus microplus. Insect Biochem. Mol. Biol. 2002, 32, 1805-1811. [CrossRef]

132. Logullo, C.; da Silva Vaz, I.J.; Sorgine, M.H.; Paiva-Silva, P.O.; Faria, F.S.; Zingali, R.B.; De Lima, M.F.; Abreu, L.; Oliveira, E.F.; Alves, E.W.; et al. Isolation of an aspartic proteinase precursor from the egg of a hard tick, Boophilus microplus. Parasitology 1998, 116, 525-532. [CrossRef] [PubMed]

133. Hammerl, P.; Hartl, A.; Thalhamer, J. Improvement of antisera raised against complex antigen mixtures by the use of heterologous sources of antigen for immunization. J. Immunol. Methods 1993, 160, 155-161. [CrossRef]

134. Page, K.R.; Scott, A.L.; Manabe, Y.C. The expanding realm of heterologous immunity: Friend or foe? Cell Microbiol. 2006, 8, 185-196. [CrossRef] [PubMed]

135. Agrawal, B. Heterologous immunity: Role in natural and vaccine-induced resistance to infections. Front. Immunol. 2019, 10, 2631. [CrossRef] [PubMed]

136. Covián, C.; Fernández-Fierro, A.; Retamal-Díaz, A.; Vasquez, A.E.; Lay, M.K.; Riedel, C.A.; González, P.A.; Bueno, S.M.; Kalergis, A.M. BCG-Induced Cross-protection and development of trained immunity: Implication for vaccine design. Front. Immunol. 2019, 10, 2806. [CrossRef]

137. Welsh, R.M.; Che, J.W.; Brehm, M.A.; Selin, L.K. Heterologous immunity between viruses. Immunol. Rev. 2010, 235, 244-266. [CrossRef]

138. Torina, A.; Moreno-Cid, J.A.; Blanda, V.; Fernández de Mera, I.G.; Pérez de la Lastra, J.M.; Scimeca, S.; Blanda, M.; Scariano, M.E.; Briganò, S.; Disclafani, R.; et al. Control of tick infestations and pathogen prevalence in cattle and sheep farms vaccinated with the recombinant Subolesin-Major Surface Protein 1a chimeric antigen. Parasit Vectors 2014, 7, 10. [CrossRef]

139. Oldiges, D.P.; Laughery, J.M.; Tagliari, N.J.; Filho, R.V.L.; Davis, W.C.; da Silva Vaz, I.J.; Termignoni, C.; Knowles, D.P.; Suarez, C.E. Transfected Babesia bovis expressing a tick GST as a live vector vaccine. PLoS Negl. Trop. Dis. 2016, 10. [CrossRef]

140. Almazán, C.; Moreno-Cantú, O.; Moreno-Cid, J.A.; Galindo, R.C.; Canales, M.; Villar, M.; de la Fuente, J. Control of tick infestations in cattle vaccinated with bacterial membranes containing surface-exposed tick protective antigens. Vaccine 2012, 30, 265-272. [CrossRef]

141. Islam, M.M.; Odahara, M.; Yoshizumi, T.; Oikawa, K.; Kimura, M.; Su'etsugu, M.; Numata, K. Cell-penetrating peptide-mediated transformation of large plasmid DNA into Escherichia coli. ACS Synth. Biol. 2019, 8, 1215-1218. [CrossRef]

142. Patarroyo, J.H.; Portela, R.W.; De Castro, R.O.; Couto Pimentel, J.; Guzman, F.; Patarroyo, M.E.; Vargas, M.I.; Prates, A.A.; Dias Mendes, M.A. Immunization of cattle with synthetic peptides derived from the Boophilus microplus gut protein (Bm86). Vet. Immunol. Immunopathol. 2002, 88, 163-172. [CrossRef]

143. Aguirre, A.A.; Lobo, F.P.; Cunha, R.C.; Garcia, M.V.; Andreotti, R. Design of the ATAQ peptide and its evaluation as an immunogen to develop a Rhipicephalus vaccine. Vet. Parasitol. 2016, 221, 30-38. [CrossRef] [PubMed] 
144. Rodríguez-Mallon, A.; Encinosa, P.E.; Méndez-Pérez, L.; Bello, Y.; Fernández, R.R.; Garay, H.; Cabrales, A.; Méndez, L.; Borroto, C.; Mario Pablo Estrada, M.P. High efficacy of a 20 amino acid peptide of the acidic ribosomal protein P0 against the cattle tick, Rhipicephalus microplus. Ticks Tick Borne Dis. 2015, 6, 530-537. [CrossRef] [PubMed]

145. Woodruff, M.C.; Kim, E.H.; Luo, W.; Pulendran, B. B cell competition for restricted T cell help suppresses rare-epitope responses. Cell Rep. 2018, 25, 321-327. [CrossRef] [PubMed]

146. Kedl, R.M.; Rees, W.A.; Hildeman, D.A.; Schaefer, B.; Mitchell, T.; Kappler, J.; Marrack, P. T cells compete for access to antigen-bearing antigen-presenting cells. J. Exp. Med. 2000, 192, 1105-1113. [CrossRef]

147. Skwarczynski, M.; Toth, I. Peptide-based synthetic vaccines. Chem. Sci. 2016, 7, 842-854. [CrossRef]

148. Csordas, B.G.; Cunha, R.C.; Garcia, M.V.; da Silva, S.S.; Leite, F.L.; Andreotti, R. Molecular characterization of the recombinant protein RmLTI-BmCG-LTB: Protective immunity against Rhipicephalus (Boophilus) microplus. PLoS ONE 2018, 13, e0191596. [CrossRef]

149. Blecha, I.M.Z.; Csordas, B.G.; Aguirre, A.A.R.; Cunha, R.C.; Garcia, M.V.; Andreotti, R. Analysis of Bm86 conserved epitopes: Is a global vaccine against Cattle Tick Rhipicephalus microplus possible? Rev. Bras. Parasitol. Vet. 2018, 27, 267-279. [CrossRef]

150. Ndawula, C.J.; Amaral, X.M.; Villavicencio, B.; Lopes, F.C.; Juliano, M.A.; Parizi, L.F.; Verli, H.; da Silva Vaz, I.J.; Ligabue-Braun, R. Prediction, mapping and validation of tick glutathione S-transferase B-cell epitopes. Ticks Tick Borne Dis. 2020, 11, 101445. [CrossRef]

151. Khan, K.H. DNA vaccines: Roles against diseases. Germs 2013, 3, 26-35. [CrossRef]

152. Zhang, T.T.; Zhang, J.C.; Cui, X.J.; Zheng, J.J.; Li, R.; Wang, F.; Liu, J.; Hu, Y.H. Evaluation of immune protection induced by DNA vaccines from Haemaphysalis longicornis paramyosin in rabbits. Parasit Vectors 2017, 10, 325. [CrossRef] [PubMed]

153. Hassan, I.A.; Wang, Y.; Zhou, Y.; Cao, J.; Zhang, H.; Zhou, J. Cross protection induced by combined Subolesin-based DNA and protein immunizations against adult Haemaphysalis longicornis. Vaccine 2020, 38, 907-915. [CrossRef] [PubMed]

154. Obeng-Adjei, N.; Hutnick, N.A.; Yan, J.; Chu, J.S.; Myles, D.J.F.; Morrow, M.P.; Sardesai, N.Y.; Weiner, D.B. DNA vaccine cocktail expressing genotype $A$ and $C H B V$ surface and consensus core antigens generates robust cytotoxic and antibody responses in mice and Rhesus macaques. Cancer Gene Ther. 2013, 20, 652-662. [CrossRef] [PubMed]

155. Uhlír, J.; Grubhoffer, L.; Borský, I.; Dusbábek, F. Antigens and glycoproteins of larvae, nymphs and adults of the tick Ixodes ricinus. Med. Vet. Entomol. 1994, 8, 141-150. [CrossRef] [PubMed]

156. Lee, R.P.; Jackson, L.A.; Opdebeeck, J.P. Immune responses of cattle to biochemically modified antigens from the midgut of the cattle tick, Boophilus microplus. Parasite Immunol. 1991, 13, 661-672. [CrossRef] [PubMed]

157. Willadsen, P.; Riding, G.A.; McKenna, R.V.; Kemp, D.H.; Tellam, R.L.; Nielsen, J.N.; Lahnstein, J.; Cobon, G.S.; Gough, J.M. Immunologic control of a parasitic arthropod. Identification of a protective antigen from Boophilus microplus. J. Immunol. 1989, 143, 1346-1351. [PubMed]

158. Sahdev, S.; Khattar, S.K.; Saini, K.S. Production of active eukaryotic proteins through bacterial expression systems: A review of the existing biotechnology strategies. Mol. Cell Biochem. 2008, 307, 249-264. [CrossRef]

159. Peltola, H.; Käyhty, H.; Sivonen, A.; Mäkelä, H. Haemophilus influenzae type b capsular polysaccharide vaccine in children: A double-blind field study of 100,000 vaccinees 3 months to 5 years of age in Finland. Pediatrics 1977, 60, 730-737.

160. Avery, O.T.; Goebel, W.F. Chemo-immunological studies on conjugated carbohydrate-proteins: II. immunological specificity of synthetic sugar-protein antigens. J. Exp. Med. 1929, 50, 533-550. [CrossRef]

161. Ward, J.; Berkowitz, C.; Pescetti, J.; Burkart, K.; Samuelson, O.; Gordon, L. Enhanced immunogenicity in young infants of a new Haemophilus influenzae type $b(\mathrm{HIB})$ capsular polysaccharide(PRP)-diphtheria toxoid(D) conjugate vaccine. Pediatr. Res. 1984, 18, 287. [CrossRef]

162. Mäkelä, P.H. Conjugate vaccines a breakthrough in vaccine development. Southeast Asian J. Trop. Med. Public Health 2003, 34, 249-253.

163. Mitchison, N.A. T-cell-B-cell cooperation. Nat. Rev. Immunol. 2004, 4, 308-312. [CrossRef]

164. Avci, F.Y.; Li, X.; Tsuji, M.; Kasper, D.L. Carbohydrates and T cells: A sweet twosome. Semin. Immunol. 2013, 25, 146-151. [CrossRef] 
165. Vechtova, P.; Sterbova, J.; Sterba, J.; Vancova, M.; Rego, R.O.M.; Selinger, M.; Strnad, M.; Golovchenko, M.; Rudenko, N.; Grubhoffer, L. A bite so sweet: The glycobiology interface of tick-host-pathogen interactions. Parasit Vectors 2018, 11, 594. [CrossRef] [PubMed]

166. Dinglasan, R.R.; Jacobs-Lorena, M. Insight into a conserved lifestyle: Protein-carbohydrate adhesion strategies of vector-borne pathogens. Infect. Immun. 2005, 73, 7797-7807. [CrossRef] [PubMed]

167. Woodland, D.L. Jump-starting the immune system: Prime-boosting comes of age. Trends Immunol. 2004, 25, 98-104. [CrossRef] [PubMed]

168. Shetty, V.U.; Chaudhuri, P.; Sabella, C. Rationale for the immunization schedule: Why is it the way it is? Pediatr. Rev. 2019, 40, 26-36. [CrossRef] [PubMed]

169. Lu, S. Heterologous prime-boost vaccination. Curr. Opin. Immunol. 2009, 21, 346-351. [CrossRef]

170. Blobel, N.J.; Ramirez-Valdez, A.; Ishizuka, A.S.; Lynn, G.M.; Seder, R.A. Antigenic competition affects the magnitude and breadth of CD8 T cell immunity following immunization with a nanoparticle neoantigen cancer vaccine. J. Immunol. 2017, 198, 20.

171. Willadsen, P.; Smith, D.; Cobon, G.; McKenna, R.V. Comparative vaccination of cattle against Boophilus microplus with recombinant antigen $\mathrm{Bm} 86$ alone or in combination with recombinant Bm91. Parasite Immunol. 1996, 18, 241-246. [CrossRef] [PubMed]

172. Riding, G.A.; Jarmey, J.; McKenna, R.V.; Pearson, R.; Cobon, G.S.; Willadsen, P. A protective "concealed" antigen from Boophilus microplus. Purification, localization, and possible function. J. Immunol. 1994, 153, 5158-5166.

173. Seixas, A.; Leal, A.T.; Nascimento-Silva, M.C.; Masuda, A.; Termignoni, C.; da Silva Vaz, I.J. Vaccine potential of a tick vitellin-degrading enzyme (VTDCE). Vet. Immunol. Immunopathol. 2008, 124, 332-340. [CrossRef] [PubMed]

174. Leal, A.T.; Seixas, A.; Pohl, P.C.; Ferreira, C.A.S.; Logullo, C.; Oliveira, P.L.; Farias, S.E.; Termignoni, C.; da Silva Vaz, I.J.; Masuda, A. Vaccination of bovines with recombinant Boophilus Yolk pro-Cathepsin. Vet. Immunol. Immunopathol. 2006, 114, 341-345. [CrossRef] [PubMed]

175. Pérez-Sánchez, R.; Manzano-Román, R.; Obolo-Mvoulouga, P.; Oleaga, A. In silico selection of functionally important proteins from the mialome of Ornithodoros erraticus ticks and assessment of their protective efficacy as vaccine targets. Parasites Vectors 2019, 12, 508. [CrossRef]

(C) 2020 by the authors. Licensee MDPI, Basel, Switzerland. This article is an open access article distributed under the terms and conditions of the Creative Commons Attribution (CC BY) license (http://creativecommons.org/licenses/by/4.0/). 